\title{
Low Molecular Weight Hyaluronan Induces an Inflammatory Response in Ovarian Stromal Cells and Impairs Gamete Development In Vitro
}

\author{
Jennifer E. Rowley ${ }^{1}{ }^{\circledR}$, Farners Amargant ${ }^{1}{ }^{\circledR}$, Luhan T. Zhou ${ }^{1}$, Anna Galligos ${ }^{2}$, Leah E. Simon ${ }^{1}$, \\ Michele T. Pritchard ${ }^{2, *(D)}$ and Francesca E. Duncan $1, * \mathbb{D}$ \\ 1 Department of Obstetrics and Gynecology, Feinberg School of Medicine, Northwestern University, Chicago, \\ IL 60611, USA; jennifer_rowley@hms.harvard.edu (J.E.R.); farners.amargant@northwestern.edu (F.A.); \\ tracy.zhou@northwestern.edu (L.T.Z.); leahsimon2019@u.northwestern.edu (L.E.S.) \\ 2 Department of Pharmacology, Toxicology and Therapeutics, University of Kansas Medical Center, \\ Kansas City, KS 66160, USA; galligosa@hawks.rockhurst.edu \\ * Correspondence: mpritchard@kumc.edu (M.T.P.); f-duncan@northwestern.edu (F.E.D.); \\ Tel.: +913-588-0383 (M.T.P.); +312-503-2172 (F.E.D.)
}

Received: 25 November 2019; Accepted: 31 January 2020; Published: 4 February 2020

\begin{abstract}
The ovarian stroma, the microenvironment in which female gametes grow and mature, becomes inflamed and fibrotic with age. Hyaluronan is a major component of the ovarian extracellular matrix (ECM), and in other aging tissues, accumulation of low molecular weight (LMW) hyaluronan fragments can drive inflammation. Thus, we hypothesized that LMW hyaluronan fragments contribute to female reproductive aging by stimulating an inflammatory response in the ovarian stroma and impairing gamete quality. To test this hypothesis, isolated mouse ovarian stromal cells or secondary stage ovarian follicles were treated with physiologically relevant $(10$ or $100 \mu \mathrm{g} / \mathrm{mL})$ concentrations of $200 \mathrm{kDa}$ LMW hyaluronan. In ovarian stromal cells, acute LMW hyaluronan exposure, at both doses, resulted in the secretion of a predominantly type 2 (Th2) inflammatory cytokine profile as revealed by a cytokine antibody array of conditioned media. Additional qPCR analyses of ovarian stromal cells demonstrated a notable up-regulation of the eotaxin receptor $\mathrm{Ccr} 3$ and activation of genes involved in eosinophil recruitment through the IL5-CCR3 signaling pathway. These findings were consistent with an age-dependent increase in ovarian stromal expression of Ccl11, a major CCR3 ligand. When ovarian follicles were cultured in 10 or $100 \mu \mathrm{g} / \mathrm{mL}$ LMW hyaluronan for 12 days, gametes with compromised morphology and impaired meiotic competence were produced. In the $100 \mu \mathrm{g} / \mathrm{mL}$ condition, LMW hyaluronan induced premature meiotic resumption, ultimately leading to in vitro aging of the resulting eggs. Further, follicles cultured in this LMW hyaluronan concentration produced significantly less estradiol, suggesting compromised granulosa cell function. Taken together, these data demonstrate that bioactive LMW hyaluronan fragments may contribute to reproductive aging by driving an inflammatory stromal milieu, potentially through eosinophils, and by directly compromising gamete quality through impaired granulosa cell function.
\end{abstract}

Keywords: hyaluronan fragments; stroma; inflammation; ovarian biology; reproductive aging

\section{Introduction}

Fibrosis and inflammation are key hallmarks of the aging ovarian stroma [1,2]. The stroma is the extra-follicular sub-compartment of the ovary and is comprised of a heterogeneous mix of cell types including fibroblasts, smooth muscle cells, endothelial cells, theca-interstitial cells, and immune cells in addition to abundant extracellular matrix (ECM) components [3]. Ovarian follicles, the functional units of the ovary consisting of oocytes and their surrounding granulosa cells, develop 
within the stroma. The stroma provides the mechanical and signaling microenvironment in which female gametes develop. Thus, the age-dependent increase in stromal inflammation and fibrosis likely influences gamete quantity and quality, either directly or indirectly, and resembles aging in other tissues which is associated with a chronic pro-inflammatory state, referred to as "inflammaging" [4-9]. This phenomenon contributes to most, if not all, age-related pathologies across organ systems. However, the female reproductive system is unique because it shows overt signs of aging decades before other organs in the human body. Reproductive aging begins in women as early as their mid-thirties and is characterized by a significant decline in oocyte quantity and quality in the ovary, which contributes to adverse reproductive outcomes [2].

Although inflammation likely contributes to fibrosis in the aging ovarian stroma, what initiates and sustains this inflammation is unknown. Endogenous macromolecules and cellular debris, broadly termed damage-associated molecular patterns (DAMPs), initiate and maintain much of this pathogen-free inflammatory milieu in aging tissues [10]. ECM degradation is one major source of DAMPs, which can occur in response to cellular senescence, increased oxidative stress, tissue injury and/or dysregulated waste clearing mechanisms. DAMPs can in turn activate the innate immune system, leading to downstream pro-inflammatory cytokine secretion and immune cell recruitment [10-14]. One of the best characterized pro-inflammatory DAMPs is low molecular weight (LMW) hyaluronan [10,15-17].

Hyaluronan is a ubiquitous component of the ECM in mammalian organs, and we recently demonstrated that ovarian hyaluronan is localized to the stromal sub-compartment [18]. Hyaluronan is a glycosaminoglycan comprised of repeating disaccharide units forming a linear polysaccharide chain that is highly poly-disperse in length, ranging in molecular weight from under $10 \mathrm{kDa}$ to over 1.8 MDa [19]. In its high molecular weight form, hyaluronan promotes tissue hydration and homeostasis [20]. As part of normal hyaluronan turnover, larger hyaluronan molecules are depolymerized producing LMW hyaluronan fragments. These fragments are quickly cleared and do not harm surrounding tissues [21]. However, if this process becomes dysregulated, LMW hyaluronan fragments accumulate in tissue and produce an inflammatory response. The inflammatory effects of LMW hyaluronan have been documented in multiple tissues (i.e., the liver, kidney and lung) and in numerous inflammatory and fibrotic diseases [22-25]. LMW hyaluronan accumulation can occur due to increased reactive oxygen species (ROS) as well as increased abundance or bioactivity of hyaluronan degradation enzymes (hyaluronidases) [22]. Moreover, hyaluronan fragmentation is associated with aging in extra-ovarian tissues, including articular cartilage [26] and skin [27], with both hyaluronidase and ROS implicated in hyaluronan depolymerization. Ovarian antioxidant defenses decrease with advanced reproductive age with a concomitant increase in oxidative damage, which accelerates reproductive aging due to oxidative stress [28]. Because the aging ovarian microenvironment is permissive to HA fragmentation, we hypothesized that bioactive LMW hyaluronan fragments stimulate an inflammatory response in the ovarian stroma in addition to having a direct effect on the follicle.

\section{Results}

\subsection{Low Molecular Weight Hyaluronan Treatment Induces an Inflammatory Response in Ovarian Stromal Cells In Vitro}

Given the known inflammatory properties of LMW hyaluronan fragments in other tissue types, we investigated whether these fragments induced inflammatory cytokine secretion and gene expression in ovarian stromal cells. To do this, we first established and validated a primary ovarian stromal cell culture system. Isolated ovarian stromal cells grew in culture in a monolayer and increased in confluence between 24 and $48 \mathrm{~h}$ (Figure 1A,B). After $48 \mathrm{~h}$ in culture, 95.6\% of cells were alive as assessed by a live/dead staining assay, whereas $2.0 \%$ were dead and $2.4 \%$ were unstained (Figure 1C,D). The stromal cells were heterogeneous in morphology and cell type as expected [3]. Fibroblast-like cells were detected based on their elongated morphology and presence of multiple F-actin-based stress 
fibers (Figure 1E,F). Some cells also contained cytoplasmic droplets resembling cholesterol-containing lipid droplets used for steroidogenesis in theca cells (Figure 1G inset) [29]. To determine whether these cells were theca in origin, we performed staining for alkaline phosphatase (AP), which is frequently used as theca marker [3]. After $48 \mathrm{~h}$ in culture, $60 \%$ of the cells stained positive for AP (Figure 1G,H).
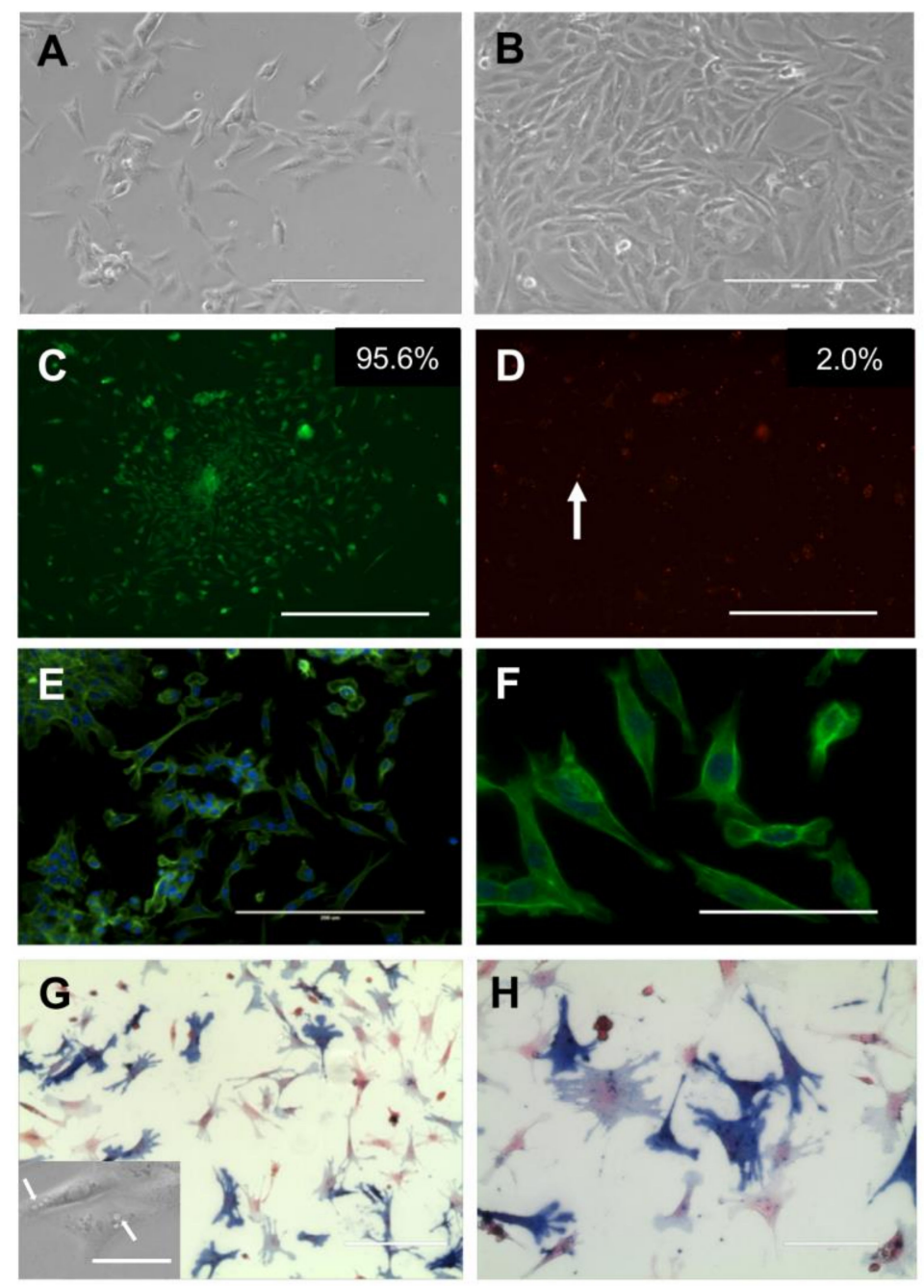

Figure 1. Stromal cell cultures are viable and predominantly theca-like after $48 \mathrm{~h}$. (A,B) Stromal cells visualized with brightfield microscopy at (A) 24 and (B) $48 \mathrm{~h}$ in culture. Scale bar $200 \mu \mathrm{m}$. (C,D) Representative corresponding images of live cells ((C), GFP)) and dead cells ((D), TxRed, arrow indicating positive dead stain)). The percentage of total cells staining positively for live and dead stains are shown in insets in $(\mathbf{C}, \mathbf{D})$, respectively. Scale bar $400 \mu \mathrm{m}$. (E,F) Low $((\mathbf{E})$, scale bar $200 \mu \mathrm{m}))$ and high $(\mathbf{F}$, scale bar $30 \mu \mathrm{m})$ magnification images of stromal cells stained for actin with 488-Phalloidin and mounted with 4',6-diamidino-2-phenylindole (DAPI). (G,H). Alkaline phosphatase staining (dark blue) to identify cells of theca origin. Low (G, scale bar $200 \mu \mathrm{m})$ and high magnification $((\mathbf{H})$, scale bar $50 \mu \mathrm{m})$ ) images. Arrow in $\mathrm{G}$ inset (scale bar $30 \mu \mathrm{m}$ ) indicates lipid droplets, a feature associated with theca cells.

Next, stromal cell cultures were incubated in the presence or absence of LMW hyaluronan for $6 \mathrm{~h}$. We chose this time point as it was used previously by others [30], and because we wanted to measure cytokine and chemokine proteins secreted by stromal cells into the culture medium. Following a $6 \mathrm{~h}$ treatment with 10 or $100 \mu \mathrm{g} / \mathrm{mL} 200 \mathrm{kDa}$ LMW hyaluronan, ovarian stromal cells showed no appreciable differences in cell morphology and confluence between the treated and untreated groups, suggesting that these concentrations of hyaluronan were non-toxic and did not trigger differentiation into other cell types (Figure 2). To examine whether LMW hyaluronan induced secretion of pro-inflammatory 
cytokines, we performed an inflammatory cytokine antibody array on conditioned media from ovarian stromal cells following culture with $10 \mu \mathrm{g} / \mathrm{mL}$ hyaluronan (Figure 3). This array profiles 62 pro- and anti-inflammatory mouse cytokines (Table S1). Despite the short treatment time of $6 \mathrm{~h}, 7$ cytokines showed differential secretion in response to LMW hyaluronan exposure ( $>1.45$ fold-change): IL4 (3.25 \pm 0.58 -fold change), IL5 ( $2.00 \pm 0.36$-fold change), IL6 (1.81 \pm 0.92 -fold change), IL12 p70 (1.72 \pm 0.75 -fold change), IL13 (3.00 \pm 0.85 -fold change), CXCL5 (2.16 \pm 0.18 -fold change), and TNFRSF1A (2.02 \pm 1.38 -fold change) (Figure 3). No cytokines measured were down-regulated (defined as $<0.55$ fold-change). Because these data were generated with only two replicates, we did not perform a statistical test for significance.
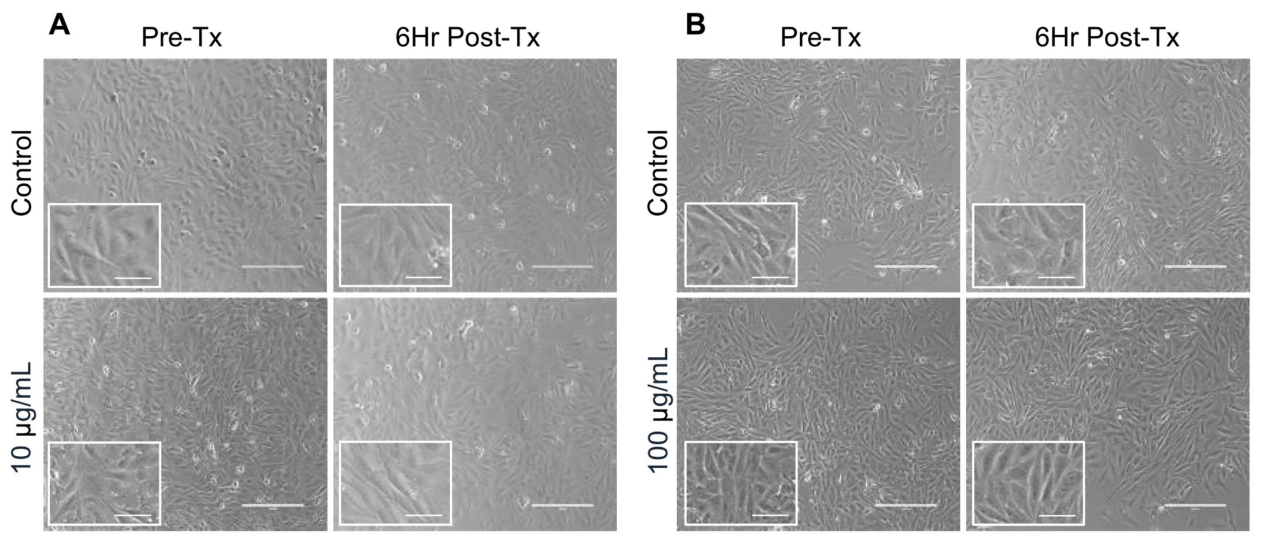

Figure 2. Ovarian stromal cell morphology and confluence is unchanged after 10 or $100 \mu \mathrm{g} / \mathrm{mL}$ low molecular weight hyaluronan treatment. Stromal cells were imaged using brightfield microscopy at $42 \mathrm{~h}$ in culture before hyaluronan treatment and after $6 \mathrm{~h}$ of hyaluronan treatment at $10 \mu \mathrm{g} / \mathrm{mL}$ (A) and $100 \mu \mathrm{g} / \mathrm{mL}$ (B). Scale bars $200 \mu \mathrm{m}$. Inserts show high magnification brightfield images. Scale bars $75 \mu \mathrm{m}$.
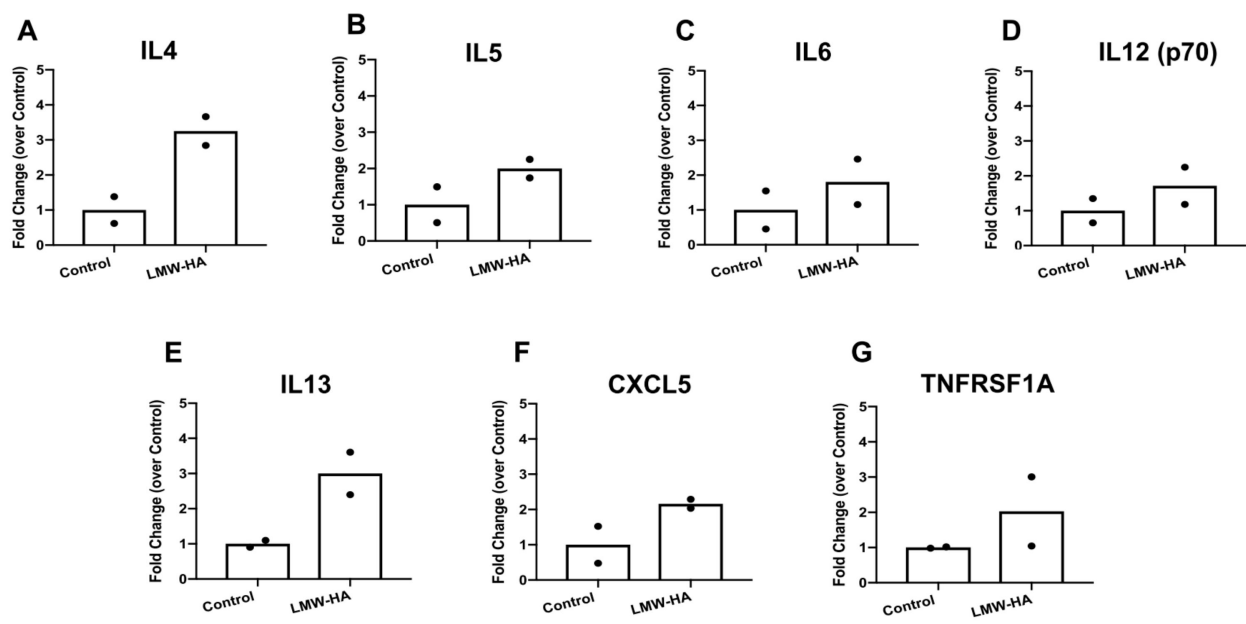

Figure 3. Treatment with $10 \mu \mathrm{g} / \mathrm{mL}$ low molecular weight (LMW) hyaluronan differentially expresses 7 inflammatory cytokines at the protein level. Using a cytokine array, 62 secreted cytokine protein levels were measured in conditioned media after $10 \mu \mathrm{g} / \mathrm{mL}$ LMW hyaluronan treatment. Of the 62 cytokines measured, 7 were differentially expressed: (A) IL4, (B) IL5, (C) IL6, (D) IL12 (p70), (E) IL13, (F) CXCL5, (G) TNFSRF1A. The bars represent the average of $n=2$ replicates. Individual data points are shown.

To further characterize the immune response of ovarian stromal cells following LMW hyaluronan treatment, gene expression patterns in treated versus untreated cells were compared using an inflammatory cytokine and cytokine receptor qPCR array which interrogates the expression of genes encoding select chemokines, inflammatory cytokines and interleukins, as well as their receptors, which mediate inflammation (Table S2). This analysis was performed using the same stromal cells whose 
conditioned media were analyzed for cytokine and chemokine proteins (Figure 3). Treatment with $10 \mu \mathrm{g} / \mathrm{mL}$ LMW hyaluronan resulted in differential gene expression in sixteen inflammatory genes ( $>1.45$ or $<0.55$ fold-change) (Figure 4 , Table 1). Eleven of the sixteen differentially expressed genes encoded for chemokines $(\mathrm{Ccl} 3, \mathrm{Ccl} 6, \mathrm{Ccl}, \mathrm{Ccl12}, \mathrm{Ccl19}, \mathrm{Cx} 3 \mathrm{cl1}, \mathrm{C} x \mathrm{cl} 5)$ or chemokine receptors $(\mathrm{Ccr} 3$, Cor4, Ccr10, Cxcr3).

Table 1. Differentially expressed inflammatory genes in ovarian stromal cells following 10 and 100 $\mu \mathrm{g} / \mathrm{mL}$ LMW hyaluronan treatment.

\begin{tabular}{|c|c|c|c|}
\hline \multirow[t]{2}{*}{ Gene Type } & \multirow[t]{2}{*}{ Gene } & \multicolumn{2}{|c|}{ Fold Change } \\
\hline & & $\begin{array}{l}10 \mu \mathrm{g} / \mathrm{mL} \\
\text { LMW-HA }\end{array}$ & $\begin{array}{l}100 \mu \mathrm{g} / \mathrm{mL} \\
\text { LMW-HA }\end{array}$ \\
\hline \multirow{6}{*}{ Chemokines } & Ccl3 & 1.75 & \\
\hline & Ccl5 & & 1.61 \\
\hline & Ccl6 & 2.75 & \\
\hline & Ccl8 & 0.52 & \\
\hline & Ccl12 & 1.94 & \\
\hline & Ccl19 & 1.46 & 0.52 \\
\hline \multirow{9}{*}{$\begin{array}{l}\text { Chemokine } \\
\text { Receptors }\end{array}$} & Ccr3 & 4.07 & 3.57 \\
\hline & Ccr4 & 1.53 & \\
\hline & Ccr5 & & 0.19 \\
\hline & Ccr6 & & 0.35 \\
\hline & Ccr8 & & 0.32 \\
\hline & Ccr10 & 2.48 & \\
\hline & Cx3cl1 & 1.47 & \\
\hline & Cxcl5 & 2.19 & \\
\hline & Cxcr3 & 0.44 & \\
\hline \multirow{6}{*}{ Interleukins } & $I l 1 \alpha$ & & 2.63 \\
\hline & $I l 1 B$ & 1.91 & \\
\hline & Il4 & & 4.16 \\
\hline & Il5 & 0.42 & 0.02 \\
\hline & Il15 & & 0.50 \\
\hline & Il16 & & 0.52 \\
\hline \multirow[t]{2}{*}{$\begin{array}{l}\text { Interleukin } \\
\text { Receptors }\end{array}$} & $I l 2 r b$ & & 0.51 \\
\hline & Fasl & & 0.44 \\
\hline \multirow{4}{*}{ Other Cytokines } & Lta & 0.18 & \\
\hline & $L t b$ & & 0.43 \\
\hline & $\operatorname{Tnfsf10}$ & 0.41 & \\
\hline & Tnfsf11 & & 0.27 \\
\hline $\begin{array}{l}\text { Other Cytokine } \\
\text { Receptors }\end{array}$ & Tnfrsf11b & 1.46 & \\
\hline
\end{tabular}

The majority of these eleven chemokine-related genes showed up-regulated expression following treatment relative to controls except for $\mathrm{C} c l 8$ and $\mathrm{Cxcr3}$, which exhibited a down-regulation. The remaining five differentially regulated genes included two interleukins (Ill $\beta$ and Il5), as well as three other cytokines and cytokine receptors (Lta, Tnfsf10, Tnfrsf11b). These five genes showed a mix of up-regulation (Il1 $\beta$, Tnfrsf11b) and down-regulation (Il5, Lta, Tnfsf10). We performed a similar gene expression analysis following treatment with $100 \mu \mathrm{g} / \mathrm{mL}$ LMW hyaluronan and found that this higher concentration condition also induced differential patterns of gene expression (Table 1, Supplemental Figure S1). 


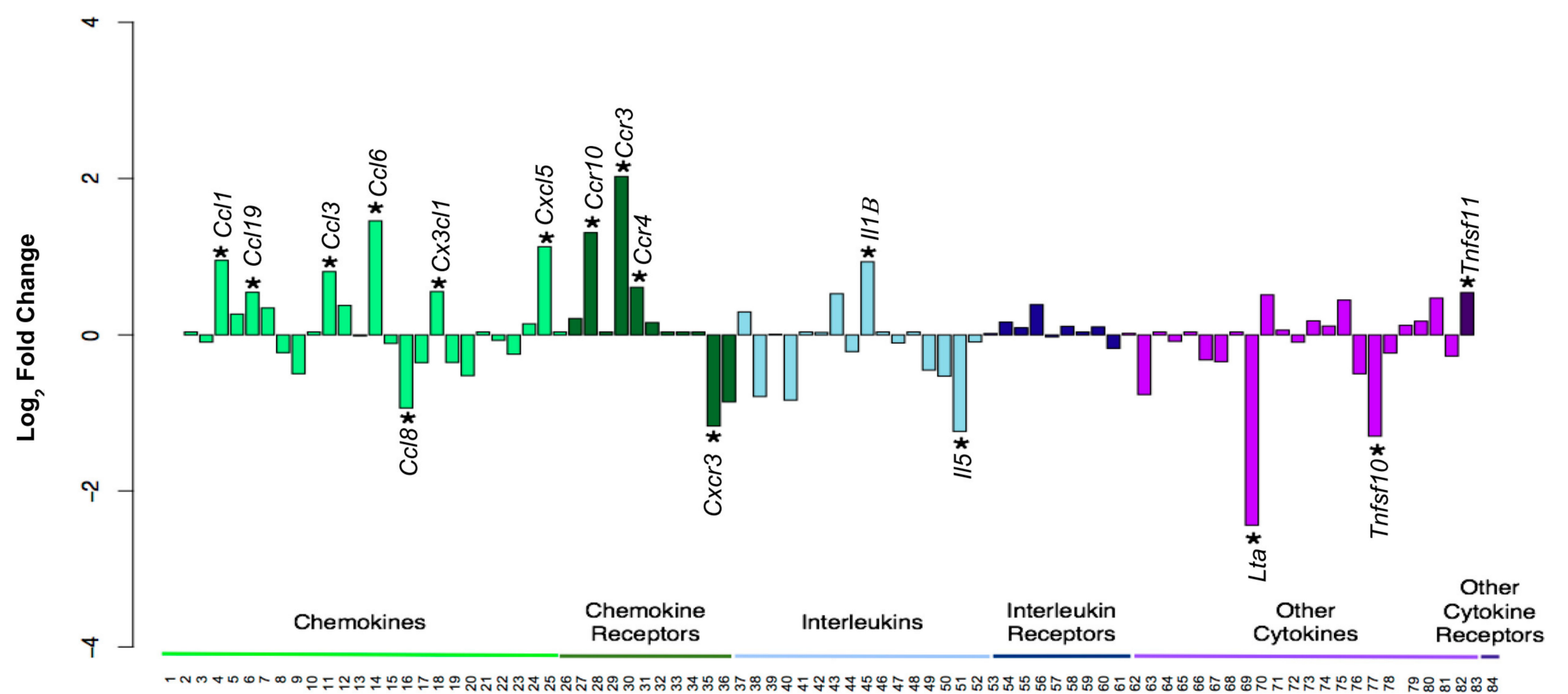

\section{Gene Types}

Figure 4. Treatment with $10 \mu \mathrm{g} / \mathrm{mL}$ LMW hyaluronan results in differential expression of inflammatory genes. Gene expression fold changes for all 84 genes were $\log _{2}$ transformed to show expression changes relative to zero, and plotted by inflammatory gene type. Gene types include "Chemokines", "Chemokine Receptors", "Interleukins", "Interleukin Receptors", "Other Cytokines" and "Other Cytokine Receptors". Up-regulation was defined as a fold change of 1.45 (equivalent to 0.54 on this graph) and down-regulation was defined as 0.55 (equivalent to -0.86 on this graph) were indicated with an asterisk $\left({ }^{*}\right)$. 
2.2. Genes Involved in IL5-CCR3-Mediated Eosinophil Differentiation, Recruitment, and Maturation Were Differentially Regulated Following LMW Hyaluronan Treatment

Eosinophils are major effector cells of Th2 immunity and are implicated in numerous chronic inflammatory responses [31-33]. Interestingly, we observed that Ccr3 and Il5, which are both strongly associated with eosinophil recruitment and differentiation, showed consistent patterns of gene expression across both hyaluronan treatment concentrations. Ccr3 expression increased in response to LMW hyaluronan relative to controls ( $10 \mu \mathrm{g} / \mathrm{mL}: 4.06$-fold and $100 \mu \mathrm{g} / \mathrm{mL}: 3.57$-fold), whereas Il5 expression decreased ( $10 \mu \mathrm{g} / \mathrm{mL}: 0.42$-fold and $100 \mu \mathrm{g} / \mathrm{mL}$ : 0.02-fold) (Figure 5A). However, at the protein level, IL5 secretion increased following LMW hyaluronan treatment (Figure 3). Twenty of the 84 total genes included in the array are associated with IL5-CCR3 regulation of eosinophils in the context of inflammation. These genes include: CCR3 ligands (Ccl11, Ccl2, Ccl24, Ccl5, Ccl7, Ccl8), regulators of CCR3 ligand expression (Il4 and Il13), regulators of $\mathrm{Ccr} 3$ expression or CCR3 function (Csf2, Cxcl9, Cxcl10, Cxcl11, Cxcr3, Ifng, Il5, Il5ra, Tnf, Tnfrsf11b, Tnfsf10), and finally Ccr3 itself. Using a hypergeometric distribution statistical test [34,35], we found that significantly more IL5-CCR3-related genes are differentially regulated after LMW hyaluronan treatment than would be expected by chance $(p=0.044)$ (Figure 5B).
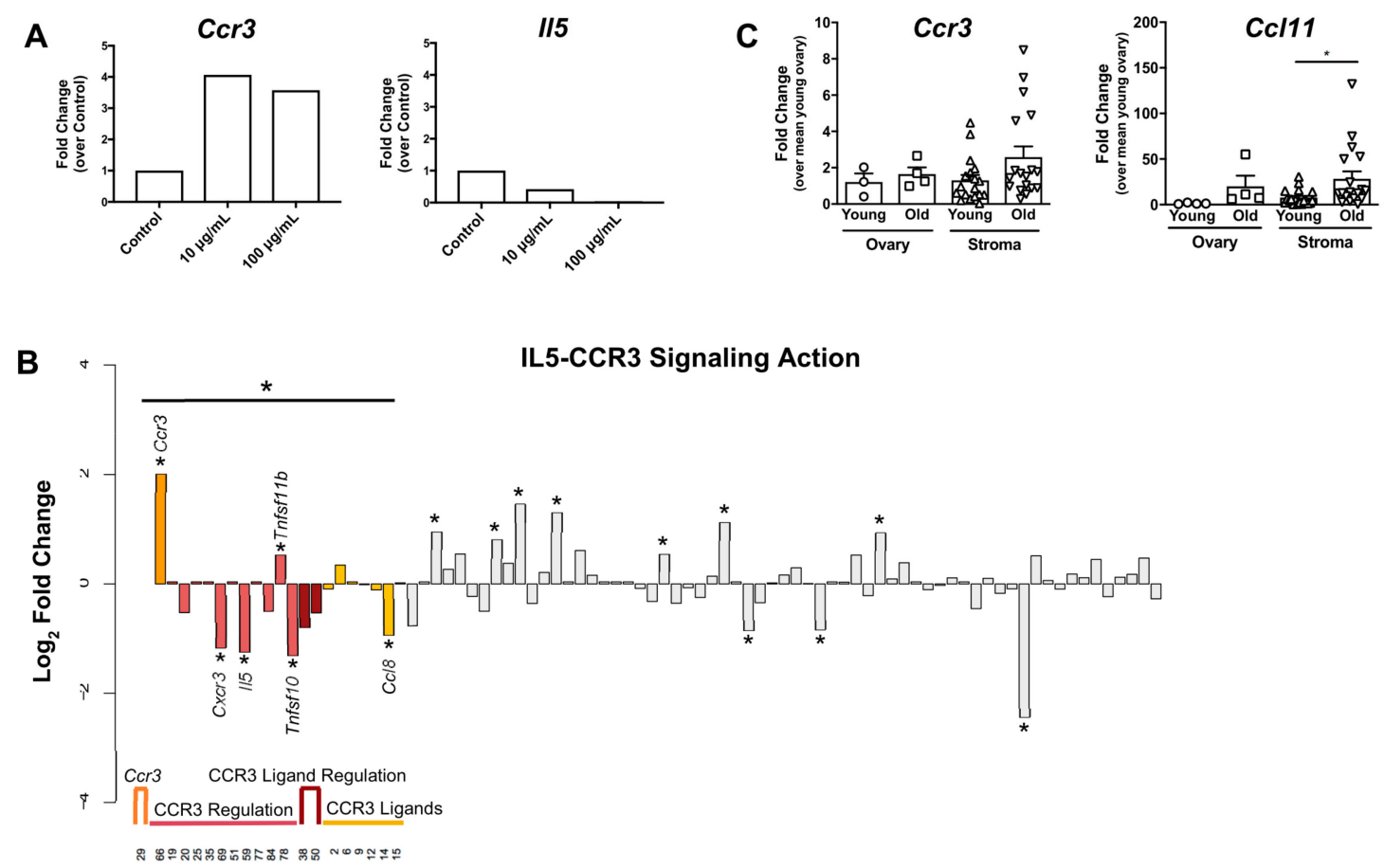

Figure 5. Genes involved in IL5-CCR3-mediated differentiation, recruitment and maturation of eosinophils are differentially expressed LMW hyaluronan treatment in vitro and with age in vivo. (A) Ccr3 and Il5 expression patterns identified by qPCR array $6 \mathrm{~h}$ after 10 or $100 \mu \mathrm{g} / \mathrm{mL}$ LMW hyaluronan treatment $n=2$. (B) A hypergeometric distribution test was performed on 20 of 84 array genes involved in IL5-CCR3-mediated eosinophil activation: Ccr3 (orange), genes that regulate Ccr3 expression or CCR3 activity (light red), genes that regulate CCR3 ligand expression or activity (dark red), and genes encoding CCR3 ligands (yellow). Using this test, significantly more genes involved in this pathway were differentially regulated $(*,>1.45$ fold-change relative to controls) following LMW hyaluronan treatment than would be expected by chance. (C) qPCR analysis was performed using ovaries or ovarian stromal tissue from reproductively young and old mice to compare expression of Ccr3 and Ccl11, a major effector of IL5-CCR3-mediated eosinophil chemotaxis in inflammatory responses. $n=3-20$. Error bars show standard error of the mean. 
To determine whether these findings may have physiologic significance in the context of reproductive aging, we compared gene expression patterns in whole ovaries and ovarian stromal husks in reproductively old mice versus reproductively young mice. Using qPCR analysis, we observed a consistent trend in the age-dependent increase in $C \mathrm{cr} 3$ expression in both the ovarian stroma $(2.58 \pm 2.48$-fold change over young whole ovary, $p=0.0588)$ and the whole ovary $(1.65 \pm 0.73$-fold change over young whole ovary, $p=0.491$ ), consistent with our in vitro results (Figure 5C). Further, Ccl11, the major ligand for Ccr3 which selectively regulates eosinophil trafficking in inflammatory contexts [36,37], showed a significant increase in reproductively old stroma (28.32 \pm 34 .11-fold change over young whole ovary, $p=0.0151)$. In the reproductively old whole ovary, the increase in Ccl11 expression was not significant $(20.05 \pm 23.52$-fold change over young whole ovary, $p=0.1590)$ (Figure 5C).

\subsection{Low Molecular Weight Hyaluronan Does not Compromise Follicle Growth or Survival but Does Reduce} Estradiol Production during eIVFG

Within the ovary, follicles themselves may be targets of LMW hyaluronan in addition to the stroma. To determine the direct effect of LMW on the ovarian follicle during folliculogenesis, we used an encapsulated in vitro follicle growth (eIVFG) system. Secondary stage follicles were cultured in alginate beads, and follicle morphology, survival, and growth were tracked over 12 days. Treatment with either LMW hyaluronan concentration $(10$ or $100 \mu \mathrm{g} / \mathrm{mL})$ did not affect gross follicle morphology or follicle survival and growth relative to controls (Figure 6A,B). At both concentrations, follicle survival was above $80 \%$ in the treatment and control groups at day 12 (Figure $6 \mathrm{C}, \mathrm{D}$ ). On day 0 of culture, follicles of equal diameter were placed into treatment and control conditions $(10 \mu \mathrm{g} / \mathrm{mL}$ : $127.7 \pm 4.2 \mu \mathrm{m}$ treatment versus $127.4 \pm 4.9 \mu \mathrm{m}$ control; $100 \mu \mathrm{g} / \mathrm{mL}: 129.5 \pm 7.3 \mu \mathrm{m}$ treatment versus $131.9 \pm 7.8 \mu \mathrm{m}$ control) (Figure $6 \mathrm{E}, \mathrm{F}$ ). By day 8 of culture, $10 \mu \mathrm{g} / \mathrm{mL}$ treated follicles had an average diameter of $202.9 \pm 25.1 \mu \mathrm{m}$ compared to controls with an average diameter of $197.2 \pm 9.2 \mu \mathrm{m}(p=0.681)$. Similarly, in the $100 \mu \mathrm{g} / \mathrm{mL}$ condition, day 8 follicles had grown to an average of $230.0 \pm 23.8 \mu \mathrm{m}$ in the treated group and $235.9 \pm 11.9 \mu \mathrm{m}$ in the control group $(p=0.720)$. Thus, follicle growth was not affected by LMW hyaluronan treatment, resulting in growth curves that were indistinguishable between experimental and control groups (Figure 6E,F). Furthermore, follicles in all experimental groups reached the large antral stage at the end of the culture period.

To investigate how LMW hyaluronan exposure impacted the function of granulosa cells, $17 \beta$-estradiol concentrations were measured in the conditioned media [38]. Following treatment with $10 \mu \mathrm{g} / \mathrm{mL}$ LMW hyaluronan, follicles consistently produced less estradiol than controls on day $0,4,8$ or day 12, although this was not statistically significant (Figure 6G). Similarly, follicles treated with $100 \mu \mathrm{g} / \mathrm{mL}$ LMW hyaluronan produced less estradiol on every day of culture, and this was significant on day 8 of culture $(72.2 \pm 19.1 \mathrm{pg} / \mathrm{mL}$ treated vs. $123.8 \pm 2.7 \mathrm{pg} / \mathrm{mL}$ control, $p=0.0098)$ (Figure $6 \mathrm{H})$. 


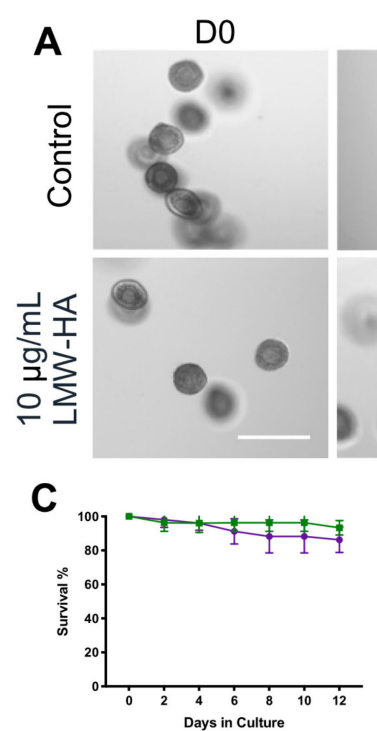

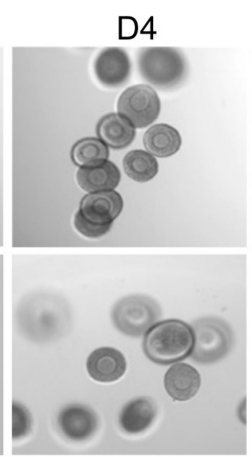
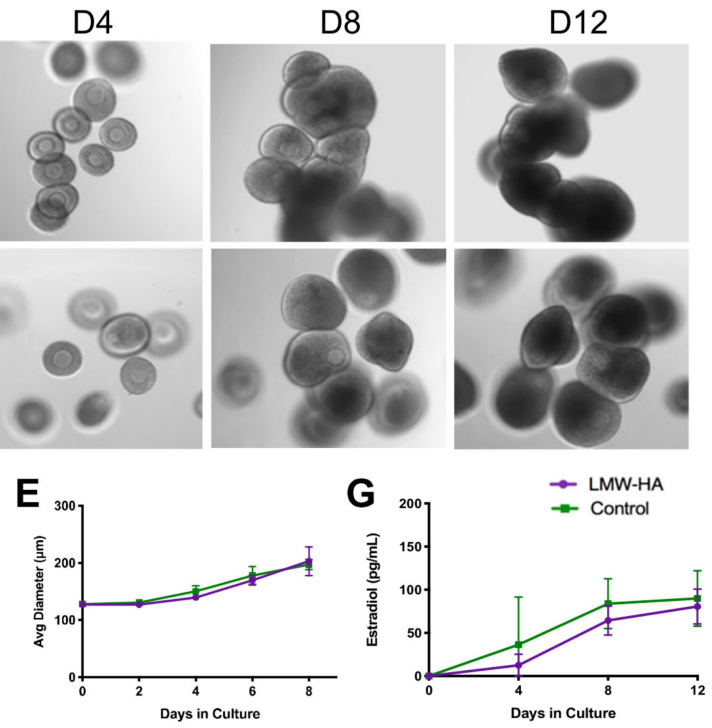

Days in Culture

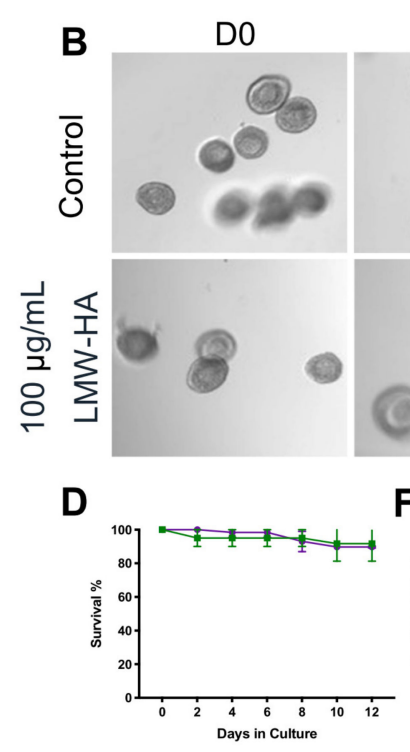

D4
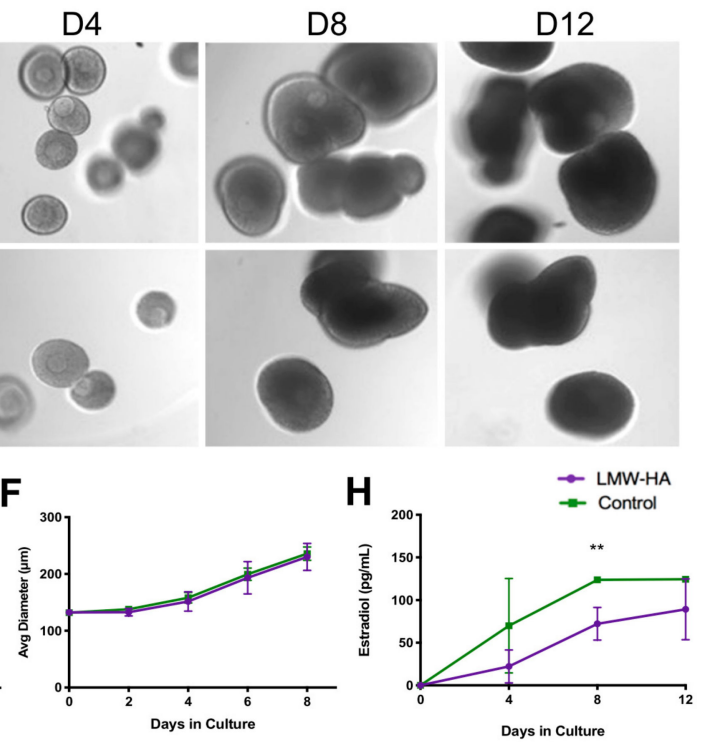

Figure 6. Treatment with 10 or $100 \mu \mathrm{g} / \mathrm{mL}$ LMW hyaluronan does not impact follicle morphology, survival or growth but does reduce estradiol production in an encapsulated in vitro growth system. Three or more follicle cultures were performed with both $10 \mu \mathrm{g} / \mathrm{mL}(n=102$ treated and 54 control follicles) and $100 \mu \mathrm{g} / \mathrm{mL}$ ( $n=74$ treated and 40 control follicles) $200 \mathrm{kDa}$ LMW hyaluronan (LMW-HA) treatment conditions. Representative images for the $10 \mu \mathrm{g} / \mathrm{mL}$ and $100 \mu \mathrm{g} / \mathrm{mL}$ cultures on day $0,4,8$ and 12 are shown (A and B, respectively; scale bars $200 \mu \mathrm{m}$ ). Diameters and survival were tracked every other day throughout culture, with survival and growth curves shown for $10 \mu \mathrm{g} / \mathrm{mL}$ (C,E) and $100 \mu \mathrm{g} / \mathrm{mL}(\mathbf{D}, \mathbf{F})$ cultures. Estradiol was measured using an ELISA in conditioned follicle culture media on day $0,4,8$ and 12 for $10 \mu \mathrm{g} / \mathrm{mL}$ (G) and $100 \mu \mathrm{g} / \mathrm{mL}$ (H) cultures. Control follicle survival, growth and estradiol curves are shown in green and treated follicle survival, growth and estradiol curves are shown in purple. Error bars show standard deviation. ${ }^{* *} p=0.0098$.

\subsection{Low Molecular Weight Hyaluronan Treatment of Follicles Compromises Gamete Quality and Causes} Premature Resumption of Meiosis

While follicle growth, survival and morphology were unaffected by LMW hyaluronan treatment, a reduction in estradiol is indicative of reduced granulosa cell function, which may impact gamete quality. Thus, we next investigated morphology and meiotic competence in gametes derived from follicles treated with LMW hyaluronan. In the $10 \mu \mathrm{g} / \mathrm{mL}$ LMW hyaluronan condition, follicles produced 
a significantly higher proportion of morphologically abnormal gametes relative to controls (50.7\% versus $17.1 \%$, respectively, $p=0.0035$ ) (Figure $7 \mathrm{~A}$ ). When further examining the subset of only morphologically normal gametes, only $48.1 \%$ of gametes derived from $10 \mu \mathrm{g} / \mathrm{mL}$ LMW hyaluronan treated follicles reached metaphase of meiosis II (MII) following human chorionic gonadotropin (hCG) exposure relative to $90.0 \%$ of controls $(p=0.0213$ ) (Figure $7 \mathrm{~B})$. In addition, MII eggs from $10 \mu \mathrm{g} / \mathrm{mL} \mathrm{LMW}$ hyaluronan treated follicles had significantly smaller terminal diameters than controls $(60.7 \pm 3.4 \mu \mathrm{m}$ vs. $63.7 \pm 3.0 \mu \mathrm{m}$ respectively, $p=0.0023$ ) (Figure 7C,D).

A

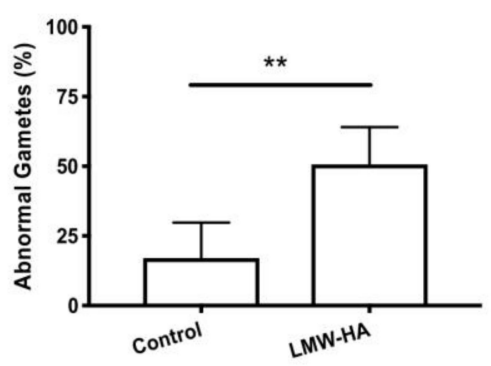

C

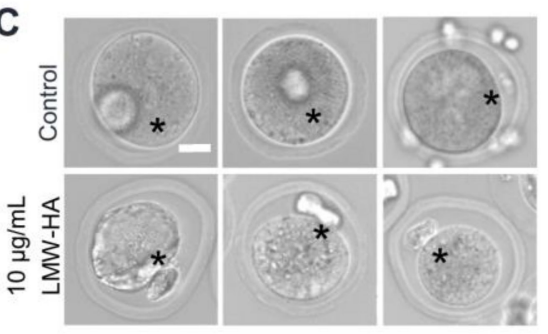

E

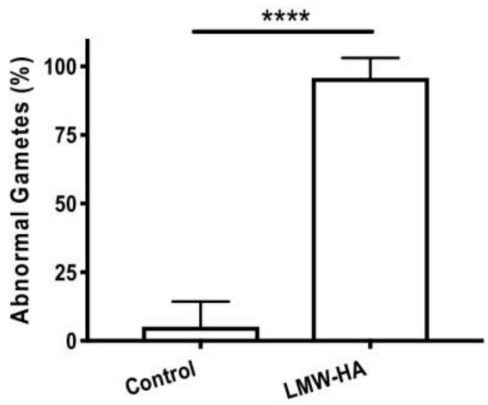

B

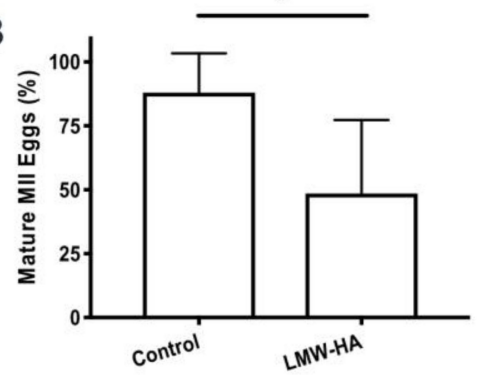

D

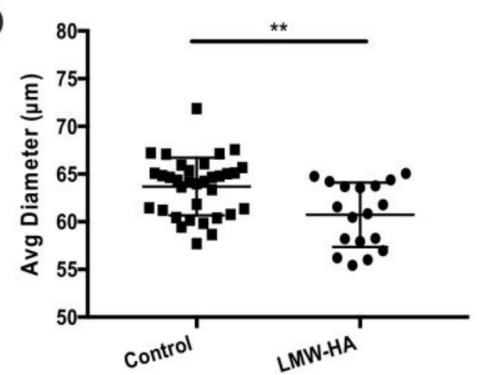

F

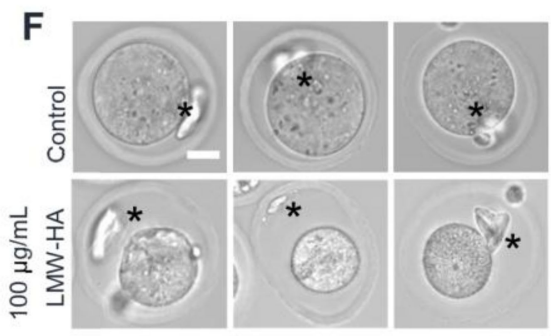

Figure 7. Treatment of follicles with $10 \mu \mathrm{g} / \mathrm{mL}$ and $100 \mu \mathrm{g} / \mathrm{mL}$ LMW hyaluronan in vitro compromises gamete quality. (A) Percent of "normal" or "abnormal" gametes after $10 \mu \mathrm{g} / \mathrm{mL}$ LMW hyaluronan treatment $(n=71)$ or control $(n=46)$ post hCG-induced ovulation ( $* * p=0.0035$, two-sample t-test). (B) Percent of mature metaphase II (MII) eggs (morphologically normal ovulated gametes with extruded polar body) ( $n=3410 \mu \mathrm{g} / \mathrm{mL}$ LMW-HA treated follicles, $n=38$ control follicles). ( $p=0.0213$, two sample t-test). (C) Representative brightfield microscopy images of MII eggs from $10 \mu \mathrm{g} / \mathrm{mL} \mathrm{LMW}$ hyaluronan treated and control follicles. Asterisks $\left(^{*}\right)$ indicate polar bodies. Scale bar $20 \mu \mathrm{m}$. (D) Mature MII egg diameters from treated $(n=18)$ and untreated $(n=34)$ follicles $(* * p=0.0023$, two-sample t-test). (E) Percent "normal" or "abnormal" gametes after $100 \mu \mathrm{g} / \mathrm{mL}$ LMW hyaluronan treatment $(n=35)$ or control $(n=34)$ after hCG-induced ovulation (**** $p<0.0001$, two-sample t-test). (F) Representative brightfield microscopy images of MII eggs from $100 \mu \mathrm{g} / \mathrm{mL}$ LMW hyaluronan treated and control follicles. Asterisks $\left(^{*}\right)$ indicate polar bodies. Scale bar $20 \mu \mathrm{m}$. Error bars show standard deviation.

In the $100 \mu \mathrm{g} / \mathrm{mL}$ LMW hyaluronan condition, this impaired gamete phenotype was more severe than the $10 \mu \mathrm{g} / \mathrm{mL}$ condition. Treated follicles produced a significantly higher proportion of abnormal gametes compared to controls $(97.4 \%$ vs. $8.8 \%$, respectively, $p<0.0001)$ (Figure $7 \mathrm{E})$. In fact, all but one 
gamete from $100 \mu \mathrm{g} / \mathrm{mL}$ LMW hyaluronan-treated follicles ( $n=35$ total, 34 abnormal) was classified as normal, which precluded evaluation of meiotic endpoints. Although the gametes derived from the $100 \mu \mathrm{g} / \mathrm{mL}$ LMW hyaluronan treated follicles had severely retracted and darkened cytoplasm, $70 \%$ of the cells possessed what appeared to be polar bodies, suggesting that they had prematurely resumed meiotic maturation and arrested at MII while still within the follicle and then undergone in vitro aging (Figure 7F). Therefore, we examined the meiotic stage of gametes within the context of intact follicles on days 8, 10 and 12 of culture without induction of ovulation (Supplemental Figure S2). At day 8 of culture, germinal vesicles (GVs), indicative of prophase I arrest, were uniformly visible across all oocytes in $100 \mu \mathrm{g} / \mathrm{mL}$ treated and control follicles as expected (Figure 8A). However, on day 10 of culture, $6.7 \%$ of follicles treated with LMW hyaluronan contained mature MII eggs, and this increased to $37.5 \%$ by day 12 , which was significant relative to untreated controls in which all oocytes were arrested at prophase I ( $p=0.026$ ) (Figure $8 \mathrm{~B}$ ). The MII eggs collected from follicles at days 10 and 12 had normal morphology with minimal perivitelline space, clear cytoplasm without visible inclusions and round polar bodies still in contact with the egg (Figure 8C).

A

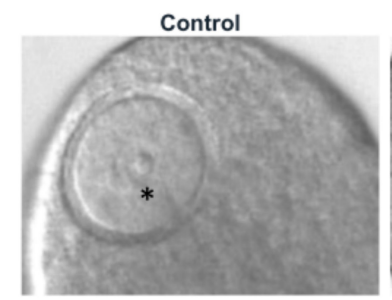

B

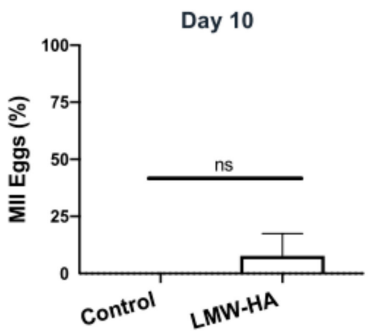

$100 \mu \mathrm{g} / \mathrm{mL}$ LMW-HA
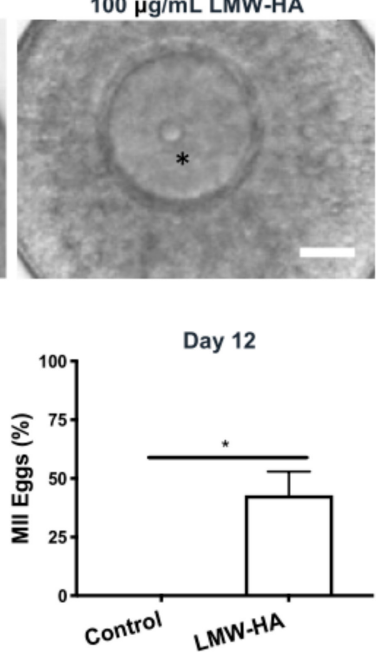

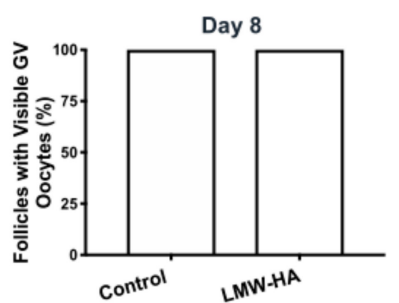

C

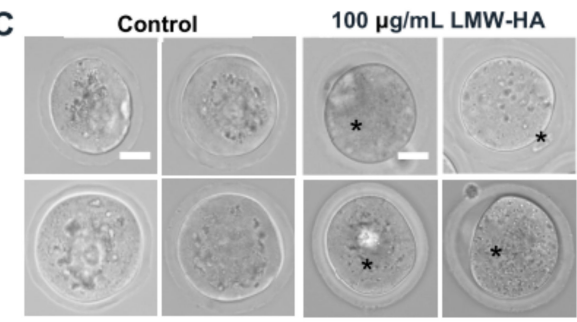

Figure 8. Follicle exposure to $100 \mu \mathrm{g} / \mathrm{mL}$ LMW hyaluronan, in vitro, triggers premature meiotic resumption in the oocyte. (A) Representative images of oocytes arrested at prophase I (intact germinal vesicles (GV, asterisks) are evidence of meiotic arrest) at day 8 in $100 \mu \mathrm{g} / \mathrm{mL}$ LMW hyaluronan treated $(n=75)$ and control $(n=43)$ follicles (left). Scale bar $20 \mu \mathrm{m}$. Percent of follicles with visible GV oocytes on day 8 (right). (B) Percent MII eggs on day 10 ( $n=75$ versus $n=43$ control follicles) and day 12 ( $n=16$ versus $n=22$ control follicles) post $100 \mu \mathrm{g} / \mathrm{mL}$ LMW-HA treatment, without hCG treatment (ns; not significant, $p=0.089, * p=0.026$ ) (two-sample t-test). Error bars show standard deviation. (C) Representative brightfield microscopy images of mature MII eggs harvested from $100 \mu \mathrm{g} / \mathrm{mL}$ LMW hyaluronan treated follicles without hCG-triggered meiotic resumption. Asterisks $\left({ }^{*}\right)$ indicates polar bodies. Scale bars $20 \mu \mathrm{m}$.

\section{Discussion}

Using two controlled in vitro systems, we have demonstrated that physiologically relevant concentrations of LMW hyaluronan exert an adverse effect on both major compartments of the ovary (i.e., the stroma and follicles). In ovarian stromal cells, a short-term treatment with 10 and $100 \mu \mathrm{g} / \mathrm{mL}$ LMW hyaluronan resulted in differential expression and secretion of numerous pro-inflammatory cytokines at the mRNA and protein levels, respectively. This was most notable for genes related to eosinophil activation. Further, while these same concentrations of LMW hyaluronan did not significantly impact folliculogenesis endpoints (i.e., follicle growth, morphology, survival), follicles exposed to these concentrations of LMW hyaluronan secreted less estradiol and produced gametes with compromised morphology and meiotic competence, suggesting impaired granulosa cell function. 
A significant portion of gametes produced from $100 \mu \mathrm{g} / \mathrm{mL}$ LMW hyaluronan-exposed follicles prematurely resumed meiosis. These findings suggest that LMW hyaluronan may be a potential driver of age-associated inflammation in the ovarian stroma. Further, these data have important implications for our understanding of how endogenous sources of tissue damage leading to hyaluronan fragmentation might contribute to the reproductive aging phenotype in both major compartments of the ovary.

In general, the ECM changes throughout the normal aging process. These changes include alterations in composition, increased macromolecule crosslinking, and ECM protein fragmentation [39]. For example, overall hyaluronan content is reduced and is often associated with a concomitant shift to lower molecular weight hyaluronan species in an age-related fashion. These observations are well-documented in articular cartilage [26] as well as in skin [27,40,41] and are paralleled, at least in part, by ultraviolet light-induced accelerated skin aging [42]. Thus, hyaluronan loss is a hallmark feature of aged tissues. The mechanisms by which hyaluronan is lost could involve reduced synthesis and increased degradation, with both enzymatic and non-enzymatic hyaluronan depolymerization proposed. Moreover, increased hyaluronan degradation products can enhance pro-inflammatory signaling and further accelerate aging-related tissue changes. Thus, LMW hyaluronan species could be one of the molecular drivers of the chronic inflammation and fibrosis observed in ovaries from reproductively old mice [1] and this is currently under investigation.

Although we do not know the identity of all cell types in our heterogeneous stromal cultures, previously published work demonstrated that immune cells are maintained [3]. Thus, we anticipate that the responses we observed were at least partly due to immune cell modulation. We have shown that hyaluronan localizes to other cell types in the ovarian stroma, such as the theca layer, so it is possible that LMW hyaluronan could be eliciting responses in other cell types as well as in immune cells [18]. Nevertheless, our stromal gene expression analyses demonstrated that LMW hyaluronan induces largely Th2-biased inflammation, and this was paralleled by secretion of a largely Th2 cytokine profile, including IL4, IL5, IL6 and IL13.

It is interesting to note that the stromal cell LMW hyaluronan response was not entirely regulated by dose. This could be because we explored gene expression at only one time point $(6 \mathrm{~h})$ after treatment. Alternatively, it is possible that the two doses elicit completely different biological pathways which is supported by the differential patterns of gene expression observed. Regardless, upon antigenic stimulation, tissue resident immune cells produce these effector cytokines to stimulate an innate immune response, typically against parasites and allergens [43]. In our system, LMW hyaluronan specifically activated genes in ovarian stromal cells that are typically responsible for the differentiation, recruitment, and maturation of eosinophils, a major effector cell of Th2 inflammatory responses, including increased Ccr3 gene expression and increased IL 5 secretion. Although consistent with an eosinophil-related signature, it is worth noting that changes in stromal cell transcript accumulation likely represent both direct LMW hyaluronan-induced changes as well as indirect changes due to cytokines, chemokines, and/or other molecules induced by LMW hyaluronan earlier in the culture period. In other systems, LMW hyaluronan has been shown to directly modulate eosinophil activation. Specifically, LMW hyaluronan treatment of eosinophils from asthma patients significantly increased their survival [44]. This effect is partially mediated by hyaluronan's primary receptor, CD44, which is expressed on the surface of eosinophils. Further, hyaluronan fragment signaling through CD44 in eosinophils induces maturation $[45,46]$.

Our findings suggest that LMW hyaluronan may induce Th2 inflammatory signaling in tissue-resident immune cells in the ovarian stroma that together exert an eosinophilic response (Figure 9) [47]. LMW hyaluronan may accomplish this by dysregulating expression of specific pathways, such as the IL5-CCR3 signaling cascade, that are involved in eosinophil differentiation, recruitment, and maturation. In response to inflammatory stimuli in a tissue, IL5 is released, by local sentinel immune cells into the blood stream which stimulates production of eosinophils by committed bone marrow progenitor cells [31]. Eosinophils released from the bone marrow then home 
to peripheral tissue undergoing an inflammatory response by upregulating CCR3, as this receptor is vital for responding to several chemotactic factors [48]. Expression of CCR3 on eosinophils is stimulated by cytokines released from immune cells, particularly IL5 [47,49-51]. Our proposed model is corroborated by our in vivo observations in the aging ovarian stroma, which revealed a nearly 28-fold expression change in Col11, the gene that encodes the potent chemoattractant CCL11, which serves as the primary ligand of CCR3 [36]. This model would account for the significant up-regulation in $\mathrm{Ccr} 3$ expression in vitro and $\mathrm{Ccl11}$ expression in vivo. Although supported by the present data, this model is currently speculative and under further investigation. However, a recently published study corroborates this model by showing a significant increase in eosinophils when comparing ovarian leukocyte populations in 3-month-old vs. 15-month-old mice [52].

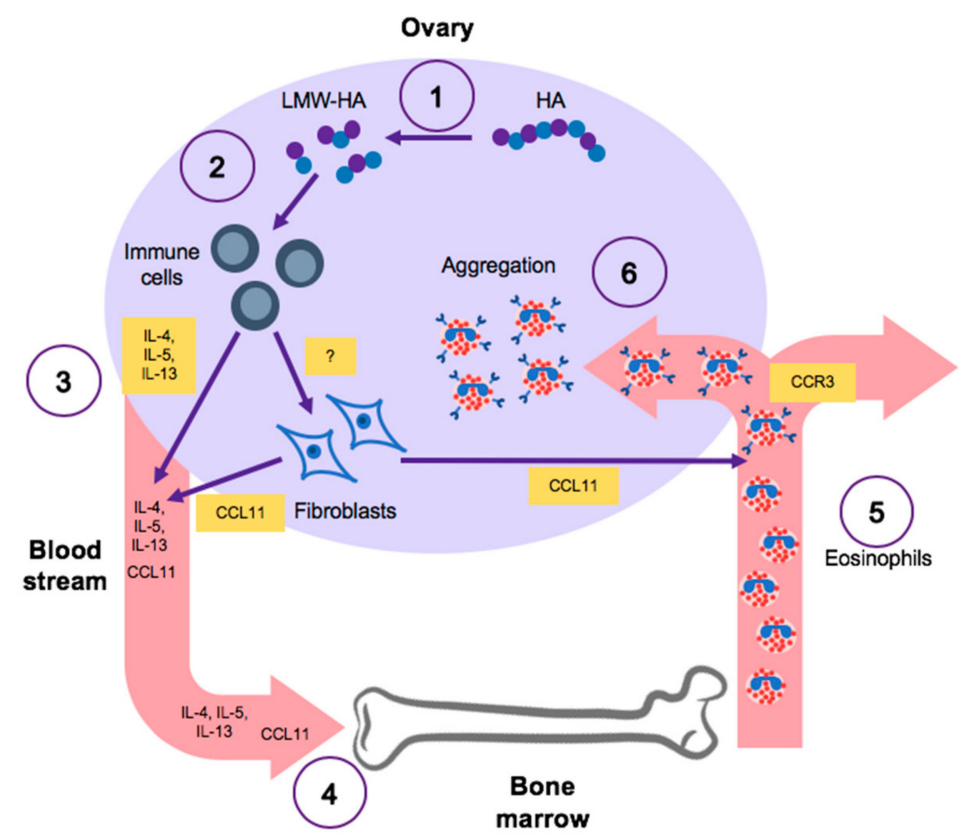

Figure 9. Schematic of potential model of LMW hyaluronan-driven inflammation in the stroma. (1) With age, the ovarian stroma likely becomes more permissive of HA fragmentation into LMW hyaluronan (LMW-HA) due to increased enzymatic (hyaluronidase) and/or non-enzymatic (ROS species) mechanisms. This leads to an accumulation of bioactive LMW hyaluronan in the ovarian stroma. (2) LMW-HA binds to receptors on tissue resident immune cells in the ovarian stroma, which in turn triggers inflammatory signaling. (3) Ovarian tissue resident immune cells mount a systemic Th2 inflammatory response by releasing Th2 pro-inflammatory cytokines (IL4, IL5, IL13) into the blood stream. It is possible that these same immune cells secrete factors that could stimulate fibroblasts in the ovarian stroma to release chemokines capable of promoting immune cell recruitment into the tissue and stimulating production of immune cells in the bone marrow, such as CCL11. (4) Secreted cytokines and chemokines trigger production of innate immune cells, such as eosinophils, in the bone marrow. (5) Innate immune cells are released into blood stream and undergo subsequent maturation by expressing key chemokine receptors, such as CCR3, which facilitate their recruitment into ovarian tissue. (6) Mature eosinophils are recruited into ovarian stroma in response to ovarian stromal LMW hyaluronan.

Our results suggest a potential role for eosinophils in driving age-related chronic inflammation in the ovary. While few studies have examined eosinophils in ovarian immune function and dysfunction, several clinical reports have documented cases of eosinophilic oophoritis $[33,53,54]$. These reports confirm that in humans, excess eosinophil recruitment in the ovary can cause significant and dysregulated inflammation, resulting in tissue damage. However, there is also evidence that eosinophils facilitate some ovarian functions under homeostatic conditions. For example, eosinophils assist with corpus luteum regression [55,56]. In other tissues, while eosinophils are best known for 
their responsiveness to allergens and parasites, these immune cells also recognize and respond to numerous endogenous DAMPs, including LMW hyaluronan [56]. Excessive endogenous DAMPs can also dysregulate signaling pathways that mediate eosinophil function, cytotoxicity, and abundance in tissue - a phenomenon implicated in several chronic inflammatory and fibrotic pathologies, such as asthma and eosinophilic esophagitis [33].

While LMW hyaluronan accumulation may drive reproductive aging by inducing stromal inflammation, our data also suggest that it may directly contribute to a reduction in granulosa cell function, resulting in a decline in gamete quality. Previous studies from our group have demonstrated that follicles from reproductively old mice assume a striking inflammatory pattern of gene expression [57]. It is possible that endogenous sources of inflammation, such as LMW hyaluronan, may be triggering these pathways in the follicle, and this warrants further investigation.

In this study, we used an eIVFG system to investigate whether LMW hyaluronan impacts the follicle compartment of the ovary. Preceding ovulation, dormant follicles in the ovary are activated and undergo extensive growth and development during folliculogenesis. Across several species, the eIVFG system has been used to successfully mature early stage follicles by maintaining vital oocyte-granulosa cell interactions over the course of long-term culture and has ultimately resulted in the production of fertilizable oocytes [58-60]. We demonstrated that follicles cultured in an eIVFG system in physiologically relevant levels of LMW hyaluronan displayed impaired readouts of granulosa function across two measures: estradiol production and maintenance of meiotic arrest, and these readouts were dose dependent. In coordination with theca cells, granulosa cells in growing follicles produce estrogens which help regulate the menstrual cycle. In previous eIVFG-based studies, estradiol levels in conditioned media were used as a marker of granulosa cell function [61,62]. LMW hyaluronan exposure reduced estradiol production independent of follicle growth, survival and morphology, and this reduction was significant late in culture. The observation that a significant difference is not reached until later in the culture is not surprising given that it takes time for estradiol to accumulate in the conditioned media. Our findings are likely biologically relevant because the mean estradiol levels are consistently lower in follicles treated with both doses of LMW hyaluronan at all time points compared to untreated follicles. Furthermore, the reduction in estradiol in response to LMW hyaluronan occurs coordinately with a premature resumption of oocyte meiosis within the context of an intact follicle. These phenotypes are both consistent with compromised granulosa cell function.

Meiosis in mammalian oocytes begins during embryonic development and arrests in late prophase of meiosis I. Oocytes remain at this meiotic stage until the LH surge signals mature follicles to resume meiosis and ovulate. Granulosa cells play a critical role in maintaining meiotic arrest of oocytes in prophase I, which can be sustained for upwards of 50 years in the human [63]. In the preovulatory follicle, meiotic arrest is in part dependent on inhibitory molecules, such as cyclic GMP (cGMP) which is produced by granulosa cells and diffuses into the oocyte through gap junctions [64]. LH binding to the outermost granulosa cells in the follicle leads to broad reduction of cGMP across all granulosa cells and in turn the oocyte, thus allowing for meiotic resumption in coordination with ovulation $[65,66]$. If granulosa cell function is altered, their ability to maintain meiotic arrest in the oocyte may be compromised. For example, resumption of meiosis can occur from blocking signaling between the oocyte and somatic cells $[67,68]$. It is also possible that meiotic resumption can occur with increased signaling through meiotic activation pathways, such as the MAPK/ERK1/2 pathway [67,68]. The MAPK/ERK1/2 pathway is indispensable for germinal vesicle breakdown (GVBD) and meiotic resumption in oocytes in mammals [68]. Interestingly, the two major hyaluronan receptors CD44 and hyaluronan-mediated motility receptor (RHAMM) are potent signaling molecules which can stimulate MAPK/ERK1/2 signaling pathways following hyaluronan binding [69]. Interestingly, LMW hyaluronan can increase signaling through MAPK/ERK1/2 via the RHAMM receptor compared to HMW hyaluronan [70]. Numerous studies have shown that signaling through these receptors impacts meiotic resumption of oocytes in pigs, blastocyst formation and quality in mice, and enhanced trophoblast growth and invasion in humans [71-73]. Thus, LMW hyaluronan may stimulate MAPK/ERK1/2 
pathway signaling in granulosa cells and thus drive premature meiotic resumption in the oocyte. Whether the result of reduced granulosa cell inhibition or directly activated meiotic resumption pathways, the significance of dysregulated timing of meiotic resumption can impact fertility. In the fallopian tube, mature eggs undergo degeneration if not fertilized. Ostensibly, mature eggs would similarly undergo degeneration if they resumed meiosis too early while still within the follicle as we observed in follicles exposed to LMW hyaluronan.

One caveat of this study is that we did not consider controls beyond omission of LMW hyaluronan in the treatment of stromal cells or follicles. Indeed, additional studies could be performed to compare 200 kDa LMW hyaluronan with high molecular weight (HMW) hyaluronan (e.g., 1 MDa). Although it would be conceptually satisfying to perform parallel studies with HMW-HA, we do not know its stability especially in culture, and it would be difficult to interpret results due to a heterogeneous composition of fragment sizes. Another potential control would be degradation of $200 \mathrm{kDa}$ LMW hyaluronan to tetra or disaccharides prior to treating stromal cells or follicles. However, these molecules could exhibit their own unique effects in ovary-derived in vitro culture systems. Equally as important as these controls would be a study identifying which hyaluronan receptor(s) are required for the observed biological effects reported here. For example, given previous work demonstrating critical importance of TLR4, CD44 and RHAMM in hyaluronan-mediated biology/pathobiology, each of these receptors could be interrogated; this is the subject of future studies.

Our exclusive use of two tightly controlled in vitro systems provided a unique opportunity to dissect the impact of LMW hyaluronan on the stromal and follicular ovarian sub-compartments independent of one another. However, this approach does have drawbacks. As mentioned above, we neither know the identity of all cell types found in the stromal cultures nor which of these cells are responding to LMW hyaluronan. Moreover, the possibility exists that an integrated response is occurring over the $6 \mathrm{~h}$ culture period which could be further dissected by including shorter time points after LMW hyaluronan treatment. However, the impact LMW hyaluronan has on follicles contained in the eIVFG system is follicle intrinsic as this system does not contain immune or other stromal cells, allowing a precise evaluation of LMW hyaluronan in this sub-compartment. Comparing all these data to those found in whole ovaries from young and old mice could corroborate the current findings, and these studies are ongoing.

Together, our findings indicate that potential products of an aging ECM can have a dual impact on both the ovarian stroma and follicles via direct or indirect mechanisms. Although restricted to in vitro systems, these results provide support implicating hyaluronan degradation products in age-related inflammation and fibrosis associated with reproductive decline in mice [1]. Moreover, this work is consistent with previously published studies that document abundant LMW hyaluronan in aging articular cartilage and skin $[26,27]$. Whether accumulation of LMW hyaluronan fragments occurs in ovarian tissue with advanced reproductive age is an active area of investigation. If this hypothesis is realized, the mechanisms by which ovarian LMW hyaluronan fragments accumulate could be due to an imbalance in hyaluronan synthesis and its degradation. Given the ovary's rapid aging relative to other organs, studying age-related DAMPs such as LMW hyaluronan in the ovarian stroma may offer novel insights into physiological changes that contribute to a chronic inflammatory and fibrotic aging phenotype in other organs. Further, to our knowledge, our findings constitute the first observations to suggest that that DAMPs produced with aging might directly impact gamete quality.

\section{Materials and Methods}

\subsection{Animals}

Reproductively young adult CB6F1 female mice (aged 3-4 weeks) were purchased from Envigo (Madison, WI, USA) and used for experiments at 6-12 weeks of age. Reproductively old CB6F1 female mice (aged 14-17 months) were procured from the Aged Rodent Colony from the National Institute of Aging. To obtain pre-pubertal mice, $\mathrm{CB} 6 \mathrm{~F} 1$ hybrids were generated by breeding Balb/c females and 
C57BL/6 males purchased from Envigo. Pre-pubertal mice were used at 12-14 days of age to maximize the yield of early stage secondary follicles. All mice were housed in a controlled barrier facility at Northwestern University's Center for Comparative Medicine (Chicago, IL, USA). Temperature, humidity and photoperiod (14 light:10 dark) were kept constant. Animals were provided food and water ad libitum. Breeder mice were fed Teklad Global irradiated chow (2920), and all other mice were fed Teklad Global irradiated chow (2916), which contain minimal phytoestrogens (Madison, WI, USA). All experiments involving animals were performed under protocols approved by the Northwestern University Institutional Animal Care and Use Committee (approved 8/30/2017) and were in accordance with the National Institutes of Health Guide for the Care and Use of Laboratory Animals.

\subsection{Ovarian Stromal Cell Isolation}

Ovarian stromal cell isolation and culture techniques were performed based on previously described methods [3]. In brief, ovaries from 6-12 week-old CB6F1 mice were removed from the bursa and placed in dissection media composed of Leibovitz's L-15 Medium (L15) (Life Technologies, Grand Island, NY, USA) supplemented with 0.5\% Penicillin-Streptomycin (Pen-Strep) (Life Technologies, Grand Island, NY, USA), and 1\% fetal bovine serum (FBS) (Life Technologies, Grand Island, NY, USA). To enrich for stromal cells, ovaries were each poked approximately 100 times with two insulin needles to release granulosa cells and oocytes. The remaining stromal husks were cut into four pieces and placed into pre-equilibrated enzymatic media comprised of $\alpha$ MEM Glutamax (Life Technologies, Grand Island, NY, USA) supplemented with $0.5 \%$ Pen-Strep and 1\% FBS, $0.7 \mathrm{mg} / \mathrm{mL}$ Collagenase IV (Thermo Fisher Scientific, Waltham, MA, USA) and $0.2 \mathrm{mg} / \mathrm{mL}$ DNAse I (Thermo Fisher Scientific, Waltham, MA, USA). The stromal husks were digested at $37^{\circ} \mathrm{C}$ in a humidified environment of $5 \%$ $\mathrm{CO}_{2}$ in air for one hour. Every $15 \mathrm{~min}$, the tissue was briefly removed from the incubator and triturated 30 times to assist with the digestion process. After $1 \mathrm{~h}$, the enzymatic digestion was quenched using an equal volume of equilibrated media with $10 \%$ FBS. The cell-containing mixture was strained through a $40 \mu \mathrm{m}$ cell strainer to remove undigested ECM and tissue (Greiner Bio-One, Kremsmünster, Austria). Cells were pelleted (1490 $\mathrm{g}$ for $5 \mathrm{~min}$ at room temperature) and washed using $5 \mathrm{~mL}$ of $37^{\circ} \mathrm{C}$ plating media (RPMI 1640 containing $25 \mathrm{mM}$ HEPES and $2 \mathrm{mM}$ L-glutamine (Invitrogen, Carlsbad, CA, USA) supplemented with 10\% FBS and 1\% Pen-Strep), three times. Cells were re-suspended in $2 \mathrm{~mL}$ plating media. A small volume of suspension $(10 \mu \mathrm{L})$ was used to count live cells using Trypan Blue Exclusion (Cat. \#T10282, Thermo Fisher Scientific, Waltham, MA, USA) and a hemacytometer. After counting, cells were plated in 4-well plates at a density of 33,000 cells $/ \mathrm{cm}^{2}$. Cells were cultured for a total of $48 \mathrm{~h}$ to minimize major changes in cell populations [3]. After $24 \mathrm{~h}$ of culture $\left(37^{\circ} \mathrm{C}, 95 \%\right.$ air $\left./ 5 \% \mathrm{CO}_{2}\right)$, wells were washed 3 times with warm PBS to remove all non-adhered cells and then imaged using brightfield microscopy on an EVOS FL Auto microscope (Life Technologies, Grand Island, NY, USA) at $4 \times, 10 \times, 20 \times$ and $40 \times$ magnifications.

\subsection{Low Molecular Weight Hyaluronan Treatment of Stromal Cell Cultures}

Eighteen hours after imaging stromal cells as described above, cells were washed 3 times with warmed PBS and media was replaced with fresh media containing 10 or $100 \mu \mathrm{g} / \mathrm{mL} 200 \mathrm{kDa}$ LMW hyaluronan (Cat. \#HA200K, Lifecore Biomedicals, Chaska, MN, USA), or fresh media without LMW hyaluronan. Although the in vivo hyaluronan concentrations in the ovary are unknown, the selected concentrations are physiologically relevant in other organs [74]. All experiments were performed with $200 \mathrm{kDa}$ LMW hyaluronan, since this size has inflammatory properties in other tissues $[16,75,76]$. Hyaluronan was certified endotoxin and protein-contamination free by the manufacturer. All treatment times were $6 \mathrm{~h}$ in length. Experiments were performed in triplicate for each treatment concentration, with duplicate wells for each condition within each experiment. 


\subsection{Cell Viability Assay}

To assess stromal cell viability after $48 \mathrm{~h}$ in culture, we used a commercial Live/Dead Assay (Cat. \#ab115347, Abcam, Cambridge, MA, USA) according to the manufacturer's protocol. Live/dead staining was visualized using an EVOS FL Auto microscope with a 20X objective (live cells: green fluorescence protein (GFP) channel (470 nm excitation; 510/42 nm emission), dead cells: Texas Red (TxRed) channel (585/29 nm excitation; 624/40 nm emission). Images in each channel were taken in 5 random regions around each well. Using the EVOS cell counting function, live cell signals were automatically counted. Dead cell signals were counted manually. Using the corresponding transmitted light images, any cells without either live or dead staining were identified. Total cell count was calculated by adding live cells, dead cells and unstained cells. Viability was reported as the average number of live cells over the total number of cells. Each assay was performed in triplicate.

\subsection{Alkaline Phosphatase and Actin Cytoskeleton Staining}

Alkaline phosphatase (AP) is a marker for theca cells, an ovarian stromal cell subtype that is associated with growing follicles and produces the androgens that granulosa cells convert into estrogens [77]. To assess the proportion of our stromal cell population that was comprised of theca cells, AP staining was performed as previously described [3]. In brief, stromal cells adhered to the bottom of the well plate were washed three times with PBS and fixed for $5 \mathrm{~min}$ in $4 \%$ paraformaldehyde (Electron Microscopy Sciences, Hatfield, PA, USA). Cells were washed three more times in PBS. Cells were then incubated in a histochemical stain $(0.25 \mathrm{mg} / \mathrm{mL}$ naphtol AS/BI phosphate and $0.75 \mathrm{mg} / \mathrm{mL}$ fast blue salt prepared in $0.2 \mathrm{M}$ Tris- $\mathrm{HCl}, \mathrm{pH}$ 8.3) for $45 \mathrm{~min}$. Cells were washed three times with double-deionized $\mathrm{H}_{2} \mathrm{O}\left(\mathrm{dd}-\mathrm{H}_{2} \mathrm{O}\right)$ and co-stained with Nuclear Fast Red (0.5\%) for $10 \mathrm{~min}$. After three additional washes with dd $-\mathrm{H}_{2} \mathrm{O}$, cells were imaged in 5 random regions of each well using brightfield microscopy with an EVOS FL Auto and 10X and 40X objectives. The number of cells that were AP-positive out of the total number of cells were quantified and the results were corroborated by a blinded third party. Each assay was performed in triplicate.

To visualize actin-based stress fibers, we stained F-actin using Alexa Fluor 488-Phalloidin (Life Technologies, Grand Island, NY, USA). To do this, stromal cells were cultured on Poly-D-Lysine (Thermo Fisher Scientific, Waltham, MA, USA) coated cover slips (concentration $200 \mu \mathrm{g} / \mathrm{mL}$ ). Cells were washed three times with warm PBS and fixed for $5 \mathrm{~min}$ in $4 \%$ paraformaldehyde (Electron Microscopy Sciences, Hatfield, PA, USA). Cells were washed three more times in PBS and then incubated with a 1:50 dilution of Alexa Fluor 488-Phalloidin for $1 \mathrm{~h}$. After washing three more times with warm PBS, coverslips were mounted on slides with Vectashield containing DAPI (Vector Laboratories, Burlingame, CA, USA) to co-stain DNA. Slides were imaged using an EVOS FL Auto equipped with 10X and 40X objectives.

\subsection{Cytokine Antibody Array of Ovarian Stromal Cell-Conditioned Media}

To examine whether LMW hyaluronan induced an inflammatory response detectable at the protein level, conditioned media were collected from ovarian stromal cell cultures at the conclusion of the 6 -h treatment period. All media $(0.75 \mathrm{~mL}$ per well) were immediately snap frozen. Media were then thawed and pooled, where $0.25 \mathrm{~mL}$ of conditioned media from each replicate was combined and diluted with blocking buffer provided with the cytokine antibody array kit in a 1:1 dilution. Samples were then applied to a RayBio C-Series Mouse Cytokine Antibody Array C3 according to the manufacturer's protocol (RayBiotech, Norcross, GA, USA) and as described previously [1]. Fold change between untreated and treated samples were then calculated. We were unable to determine statistical significance as we only had two replicates per experimental condition, and this was required to ensure we had enough biological material to perform the protein arrays. 
4.7. Gene Expression Analysis of Ovarian Stromal Cells Using Pathway-Targeted Inflammatory Cytokine and Cytokine Receptors PCR Arrays

Inflammatory gene expression changes in ovarian stromal cells were examined following LMW hyaluronan treatment. Total RNA was extracted and isolated from cultured cells using the RNeasy Mini Kit (Cat. \#74104, Qiagen, Valencia, CA, USA) as described previously [78]. To achieve the minimum cDNA concentration required for the inflammatory gene array (see below), we reduced the volume of RNase-free water added to our cDNA mixture to $17.4 \mu \mathrm{L}(10 \mu \mathrm{g} / \mathrm{mL}$ treated and control samples) or $36 \mu \mathrm{L}(100 \mu \mathrm{g} / \mathrm{mL}$ treated and control samples). This adjustment was pre-approved by the manufacturer.

The cDNA was then pooled by treatment group and transcripts analyzed using the Mouse Inflammatory Cytokine and Cytokine Receptor RT ${ }^{2}$ Profiler PCR Array (Cat. \#PAMM-011Z, Qiagen, Valencia, CA, USA) according to the manufacturer's protocol. This array profiles the expression of 84 key genes mediating the inflammatory response, including chemokines, cytokines, interleukins and their receptors. A CFX384 (BioRad, Hercules, CA, USA) machine was used for the real time polymerase chain reaction (PCR). The 5 housekeeping genes included in the array (Actb, B2m, Gapdh, Gusb, Hsp90ab1) were used to normalize gene expression. Using the $2^{-\Delta \Delta C t}$ method, fold changes in expression were calculated for each gene in treated over control samples. Statistical significance cannot be determined because the data represent only two replicates per experimental group.

\subsection{Gene Expression Analysis of Ovarian Tissue and Ovarian Stromal Husks by qPCR}

To examine age-related changes in eosinophil-associated gene expression in the ovarian stroma in vivo, we examined $\mathrm{C} c r 3$ and $\mathrm{Ccl11}$ expression in whole ovaries as well as from stromal husks from reproductively young and old mice. Stromal husks were prepared from 20 young mice and 19 old mice as described above and were then placed in RNAlater Stabilizing Solution (Cat. \#AM7020, Thermo Fisher Scientific, Waltham, MA, USA). Whole ovaries were harvested from 4 young and 4 old mice. A bead homogenization system (FastPrep 24, MP Biomedicals) was used to homogenize stromal husks and whole ovaries in RLT buffer containing $\beta$-mercaptoethanol (RNeasy Mini Kit, Qiagen). RNA was then isolated from tissue lysates using the RNeasy Mini Kit as described above and $1 \mu \mathrm{g}$ RNA was reverse transcribed to cDNA using a High Capacity cDNA Reverse Transcription Kit (Cat. \#4368813, Thermo Fisher Scientific, Waltham, MA, USA). Real time PCR was then performed using Power SYBR Green (Invitrogen, Carlsbad, CA, USA) in a CFX384 machine (BioRad, Hercules, CA, USA). After normalizing to $18 \mathrm{~S}$ as a house keeping gene, fold changes in transcript content were calculated relative to the mean young whole ovary value, using the $2^{-\Delta \Delta C t}$ method.

\subsection{Follicle Isolation and Encapsulated In Vitro Follicle Growth (eIVFG)}

The effect of LMW hyaluronan treatment on follicle growth and survival was assessed using an established eIVFG system for studying folliculogenesis, in vitro [61,79]. Ovaries were isolated from 12-14 day-old CB6F1 female mice and placed in dissection media, and follicles were mechanically isolated. Early secondary follicles were selected based on size (between 120-140 $\mu \mathrm{m}$ ) and morphology (intact basement membrane, visible and healthy oocyte, two layers of granulosa cells) and placed into maintenance media ( $\alpha$ MEM Glutamax supplemented with $0.5 \%$ Pen-Strep and $1 \%$ FBS). To encapsulate follicles, groups of 10 follicles were pipetted into the center of $0.5 \%(\mathrm{w} / \mathrm{v})$ alginate drops $(7.5 \mu \mathrm{L})$. The alginate drops containing follicles were suspended and gently dropped into a crosslinking solution $\left(50 \mathrm{mM} \mathrm{CaCl}_{2}\right.$ and $140 \mathrm{mM} \mathrm{NaCl}$ ) for $2 \mathrm{~min}$ to solidify the hydrogel. Alginate beads were transferred to a 96-well plate with a single bead placed in each well containing $100 \mu \mathrm{L}$ of equilibrated growth media ( $\alpha$ MEM Glutamax, $3 \mathrm{mg} / \mathrm{mL}$ BSA (MP Biomedicals, Solon, OH, USA), $10 \mathrm{mIU} / \mathrm{mL}$ follicle stimulating hormone (FSH), $1 \mathrm{mg} / \mathrm{mL}$ fetuin, $0.1 \%$ insulin-transferrin-selenium (Thermo Fisher Scientific, Waltham, MA, USA)).

To assess the effect of LMW hyaluronan treatment on follicle growth and survival over long-term culture, follicles were cultured in growth media supplemented with or without 10 or $100 \mu \mathrm{g} / \mathrm{mL} \mathrm{LMW}$ 
hyaluronan in a humidified environment of $5 \% \mathrm{CO}_{2}$ in air at $37^{\circ} \mathrm{C}$ for 12 days. Half of the growth media was changed every other day, and follicles were imaged at this time using the EVOS FL Auto with $10 \times$ and $20 \times$ objectives. To track individual follicles over time, follicles were identified by their relative positions. Images were used to measure average follicle diameters, which were calculated by averaging two perpendicular measurements taken from basement membrane to basement membrane using ImageJ software (National Institutes of Health, Bethesda, MD, USA). These measurements were plotted from day 0 until day 8 to obtain follicle growth curves. Measurements were not made past day 8 , as some follicles merge together making it difficult to distinguish their basement membranes. Survival was assessed using pre-established morphological criteria [79]. Follicles were considered dead if they had an absent or unhealthy appearing oocyte and/or dark/pyknotic granulosa cells. In addition, follicles were also considered dead if any portion of their basement membrane was no longer intact. Survival data was plotted through the end of culture at day 12.

\subsection{In Vitro Maturation and Meiotic Assessment}

To assess the effect of LMW hyaluronan on oogenesis, in vitro maturation (IVM) was performed in treated and untreated follicles at 12 days of culture as previously described [79]. In brief, beads were incubated with $10 \mathrm{IU} / \mathrm{mL}$ alginate lyase (Sigma Aldrich, St. Louis, MO, USA) to release follicles from the alginate. Only morphologically healthy follicles that exhibited growth over the culture period and had an intact basement membrane at the end of culture were used for downstream analyses. Follicles were placed in $\alpha$ MEM Glutamax containing $5 \mathrm{ng} / \mathrm{mL}$ epidermal growth factor (EGF, GeneScript, Piscataway, NJ, USA), $0.2 \mathrm{mIU} / \mathrm{mL}$ FSH and $15 \mu \mathrm{g} / \mathrm{mL}$ hCG (Sigma Aldrich, St. Louis, MO, USA) for 19-20 $\mathrm{h}$ to mimic the luteinizing hormone (LH) surge. In vivo, this acute increase in LH levels triggers meiotic resumption and ovulation of oocytes from follicles. In a subset of samples, IVM was not performed and instead we manually recovered gametes from follicles on days 10 and 12 of culture after removal of the follicles from alginate with the alginate lyase. Follicles were transferred into $37^{\circ} \mathrm{C}$ L15 containing $3 \mathrm{mg} / \mathrm{mL}$ polyvinylpyrrolidone (PVP) (Cat. \# P2307, Sigma Aldrich, St. Louis, MO, USA) and $5 \mu \mathrm{L} / \mathrm{mL}$ Pen-Strep (L15/PVP/PS). Using a $100 \mu \mathrm{m}$ stripper tip, gametes were extracted from follicles and immediately transferred into L15/PVP/PS with $0.025 \%$ milrinone (a PDE3 inhibitor that blocks meiotic resumption) and $0.3 \%(\mathrm{w} / \mathrm{v})$ hyaluronidase. Following a brief incubation, cumulus cells were removed. All gametes were classified by morphological criteria (Supplemental Figure S2). First, gametes were categorized as normal or abnormal using transmitted light microscopy [80]. Next, the meiotic stage of all gametes classified as normal was assessed by light microscopy $[79,81]$. Finally, brightfield microscopy with an EVOS FL Auto microscope with 10X and 20X objectives was used to assess meiotic stage of gametes within intact follicles up until day 8 of culture. Meiotic stage was assessed using the criteria listed in Supplemental Figure S2.

\subsection{Estradiol Assays of Conditioned Follicle Growth Media from eIVFG System}

Concentrations of $17 \beta$-estradiol in the conditioned media from the eIVFG system were measured using ELISA kits (Calbiotech, Spring Valley, CA, USA) according to the manufacturer's instructions. Conditioned media were collected from follicles grown with and without LMW hyaluronan treatment ( $50 \mu \mathrm{L} /$ well per day) on day $0,4,8$ and 12 of culture. Equal volumes of media were then pooled across replicates by day according to treatment group. Media collected from wells without follicles were used as a negative control. Assays were performed in triplicate for each experimental cohort.

\subsection{Statistical Analysis}

Data analysis was performed using R programming language and GraphPad Prism software (V7, GraphPad Software, La Jolla, CA, USA). In the cytokine protein array, differentially regulated proteins were defined as up-regulated ( $>1.45$ fold-change relative to controls) or down-regulated $(<0.55$ fold-change relative to controls). For the real time PCR array, differentially expressed genes were defined as up-regulated ( $>1.45$ fold-change relative to controls) or down-regulated $(<0.55$ fold-change 
relative to controls). To avoid Type II error (i.e., a false negative finding), statistical tests were not performed on cytokine array or qPCR data. A hypergeometric distribution test was used to test whether more eosinophil-related genes were differentially regulated following LMW hyaluronan treatment than would be expected by chance [34,35]. After normality was confirmed, $t$-tests were used to compare follicle growth and survival every other day of culture, as well as estradiol concentrations comparisons and meiotic progression comparisons between ovulated gametes from eIVFG cultures. All t-tests were two-tailed. A $p$-value of $<0.05$ was considered significant.

Supplementary Materials: Supplementary materials can be found at http://www.mdpi.com/1422-0067/21/3/1036/s1.

Author Contributions: Conceptualization, funding, resources, supervision, methodology, F.E.D. and M.T.P.; project administration, F.E.D., M.T.P. and J.E.R.; investigation, formal analysis, validation, visualization, F.E.D., M.T.P., J.E.R., F.A., L.T.Z., L.E.S. and A.G.; writing, J.E.R., F.E.D. and M.T.P.; All authors have read and agreed to the published version of the manuscript.

Funding: This research was funded by the Eunice Kennedy Shriver National Institute of Child Health and Human Development (R01 HD093726 to F.E.D. and M.T.P.). The funders had no role in the design of the study; in the collection, analyses, or interpretation of data; in the writing of the manuscript, or in the decision to publish the results.

Acknowledgments: We would like to thank Mary Cowman for her technical expertise and valuable input which made our model systems more physiologically relevant. Further, we would like to thank Jiyang Zhang for sharing her technical knowledge of in vitro follicle culture systems.

Conflicts of Interest: The authors declare no conflict of interest. The funders had no role in the design of the study; in the collection, analyses, or interpretation of data; in the writing of the manuscript, or in the decision to publish the results.

$\begin{array}{ll}\text { Abbreviations } \\ \text { ECM } & \text { Extracellular matrix } \\ \text { DAMP } & \text { Damage-associated molecular signal } \\ \text { LMW } & \text { Low molecular weight } \\ \text { eIVFG } & \text { Encapsulated in vitro follicle growth } \\ \text { MII } & \text { Metaphase II } \\ \text { AP } & \text { Alkaline phosphatase } \\ \text { FSH } & \text { Follicle stimulating hormone } \\ \text { GV } & \text { Germinal vesicle } \\ \text { GVBD } & \text { Germinal vesicle breakdown } \\ \text { hCG } & \text { Human chorionic gonadotropin }\end{array}$

\section{References}

1. Briley, S.M.; Jasti, S.; McCracken, J.M.; Hornick, J.E.; Fegley, B.; Pritchard, M.T.; Duncan, F.E. Reproductive age-associated fibrosis in the stroma of the mammalian ovary. Reproduction 2016, 152, 245-260. [CrossRef] [PubMed]

2. Broekmans, F.J.; Soules, M.R.; Fauser, B.C. Ovarian aging: Mechanisms and clinical consequences. Endocr. Rev. 2009, 30, 465-493. [CrossRef] [PubMed]

3. Tingen, C.M.; Kiesewetter, S.E.; Jozefik, J.; Thomas, C.; Tagler, D.; Shea, L.; Woodruff, T.K. A macrophage and theca cell-enriched stromal cell population influences growth and survival of immature murine follicles in vitro. Reproduction 2011, 141, 809-820. [CrossRef] [PubMed]

4. Franceschi, C.; Bonafe, M.; Valensin, S.; Olivieri, F.; De Luca, M.; Ottaviani, E.; De Benedictis, G. Inflamm-aging. An evolutionary perspective on immunosenescence. Ann. N. Y. Acad. Sci. 2000, 908, 244-254. [CrossRef] [PubMed]

5. Franceschi, C.; Campisi, J. Chronic inflammation (inflammaging) and its potential contribution to age-associated diseases. J. Gerontol. A Biol. Sci. Med. Sci. 2014, 69, 4-9. [CrossRef] [PubMed]

6. Franceschi, C.; Bezrukov, V.; Blanche, H.; Bolund, L.; Christensen, K.; de Benedictis, G.; Deiana, L.; Gonos, E.; Hervonen, A.; Yang, H.; et al. Genetics of healthy aging in Europe: The EU-integrated project GEHA (GEnetics of Healthy Aging). Ann. N. Y. Acad. Sci. 2007, 1100, 21-45. [CrossRef] 
7. Chung, H.Y.; Cesari, M.; Anton, S.; Marzetti, E.; Giovannini, S.; Seo, A.Y.; Carter, C.; Yu, B.P.; Leeuwenburgh, C. Molecular inflammation: Underpinnings of aging and age-related diseases. Ageing Res. Rev. 2009, 8, 18-30. [CrossRef]

8. Jurk, D.; Wilson, C.; Passos, J.F.; Oakley, F.; Correia-Melo, C.; Greaves, L.; Saretzki, G.; Fox, C.; Lawless, C.; Anderson, R.; et al. Chronic inflammation induces telomere dysfunction and accelerates ageing in mice. Nat. Commun. 2014, 2. [CrossRef]

9. Vanhooren, V.; Desmyter, L.; Liu, X.E.; Cardelli, M.; Franceschi, C.; Federico, A.; Libert, C.; Laroy, W.; Dewaele, S.; Contreras, R.; et al. N-glycomic changes in serum proteins during human aging. Rejuvenation Res. 2007, 10, 521-531. [CrossRef]

10. Feldman, N.; Rotter-Maskowitz, A.; Okun, E. DAMPs as mediators of sterile inflammation in aging-related pathologies. Ageing Res. Rev. 2015, 24, 29-39. [CrossRef]

11. Lotze, M.T.; Deisseroth, A.; Rubartelli, A. Damage associated molecular pattern molecules. Clin. Immunol. 2007, 124, 1-4. [CrossRef] [PubMed]

12. Lotze, M.T.; Zeh, H.J.; Rubartelli, A.; Sparvero, L.J.; Amoscato, A.A.; Washburn, N.R.; Devera, M.E.; Liang, X.; Tor, M.; Billiar, T. The grateful dead: Damage-associated molecular pattern molecules and reduction/oxidation regulate immunity. Immunol. Rev. 2007, 220, 60-81. [CrossRef] [PubMed]

13. Krysko, D.V.; Agostinis, P.; Krysko, O.; Garg, A.D.; Bachert, C.; Lambrecht, B.N.; Vandenabeele, P. Emerging role of damage-associated molecular patterns derived from mitochondria in inflammation. Trends Immunol. 2011, 32, 157-164. [CrossRef] [PubMed]

14. Chen, G.Y.; Nunez, G. Sterile inflammation: Sensing and reacting to damage. Nat. Rev. Immunol. 2010, 10, 826-837. [CrossRef]

15. Yamasaki, K.; Muto, J.; Taylor, K.R.; Cogen, A.L.; Audish, D.; Bertin, J.; Grant, E.P.; Coyle, A.J.; Misaghi, A.; Hoffman, H.M.; et al. NLRP3/cryopyrin is necessary for interleukin-1beta (IL-1beta) release in response to hyaluronan, an endogenous trigger of inflammation in response to injury. J. Biol. Chem. 2009, 284, 12762-12771. [CrossRef]

16. Scheibner, K.A.; Lutz, M.A.; Boodoo, S.; Fenton, M.J.; Powell, J.D.; Horton, M.R. Hyaluronan fragments act as an endogenous danger signal by engaging TLR2. J. Immunol. 2006, 177, 1272-1281. [CrossRef]

17. Bollyky, P.L.; Bogdani, M.; Bollyky, J.B.; Hull, R.L.; Wight, T.N. The role of hyaluronan and the extracellular matrix in islet inflammation and immune regulation. Curr. Diab. Rep. 2012, 12, 471-480. [CrossRef]

18. Rowley, J.E.; Rubenstein, G.E.; Manuel, S.L.; Johnson, N.L.; Surgnier, J.; Kapitsinou, P.P.; Duncan, F.E.; Pritchard, M.T. Tissue-specific fixation methods are required for optimal in situ visualization of hyaluronan in the ovary, kidney and liver. J. Histochem. Cytochem. 2019. [CrossRef]

19. Toole, B.P. Hyaluronan is not just a goo! J. Clin. Invest. 2000, 106, 335-336. [CrossRef]

20. Weissmann, B.; Meyer, K.; Sampson, P.; Linker, A. Isolation of oligosaccharides enzymatically produced from hyaluronic acid. J. Biol. Chem. 1954, 208, 417-429.

21. Toole, B.P. Hyaluronan: From extracellular glue to pericellular cue. Nat. Rev. Cancer 2004, 4, 528-539. [CrossRef] [PubMed]

22. Monslow, J.; Govindaraju, P.; Pure, E. Hyaluronan-a functional and structural sweet spot in the tissue microenvironment. Front. Immunol. 2015, 6, 231. [CrossRef] [PubMed]

23. Collins, S.L.; Black, K.E.; Chan-Li, Y.; Ahn, Y.H.; Cole, P.A.; Powell, J.D.; Horton, M.R. Hyaluronan fragments promote inflammation by down-regulating the anti-inflammatory A2a receptor. Am. J. Respir Cell Mol. Biol 2011, 45, 675-683. [CrossRef] [PubMed]

24. Horton, M.R.; Olman, M.A.; Noble, P.W. Hyaluronan fragments induce plasminogen activator inhibitor-1 and inhibit urokinase activity in mouse alveolar macrophages: A potential mechanism for impaired fibrinolytic activity in acute lung injury. Chest 1999, 116, 17S. [CrossRef]

25. Xu, G.G.; Luo, C.Y.; Wu, S.M.; Wang, C.L. The relationship between staging of hepatic fibrosis and the levels of serum biochemistry. Hepatobiliary Pancreat Dis. Int. 2002, 1, 246-248. [PubMed]

26. Holmes, M.W.; Bayliss, M.T.; Muir, H. Hyaluronic acid in human articular cartilage. Age-related changes in content and size. Biochem. J. 1988, 250, 435-441. [CrossRef]

27. Papakonstantinou, E.; Roth, M.; Karakiulakis, G. Hyaluronic acid: A key molecule in skin aging. Dermato-Endocrinology 2012, 4, 253-258. [CrossRef]

28. Lim, J.; Luderer, U. Oxidative damage increases and antioxidant gene expression decreases with aging in the mouse ovary. Biol. Reprod. 2011, 84, 775-782. [CrossRef] 
29. Meidan, R.; Girsh, E.; Blum, O.; Aberdam, E. In vitro differentiation of bovine theca and granulosa cells into small and large luteal-like cells: Morphological and functional characteristics. Biol. Reprod. 1990, 43, 913-921. [CrossRef]

30. Horton, M.R.; Olman, M.A.; Bao, C.; White, K.E.; Choi, A.M.; Chin, B.Y.; Noble, P.W.; Lowenstein, C.J. Regulation of plasminogen activator inhibitor-1 and urokinase by hyaluronan fragments in mouse macrophages. Am. J. Physiol. Lung Cell Mol. Physiol. 2000, 279, 707-715. [CrossRef]

31. Humbles, A.A.; Lu, B.; Friend, D.S.; Okinaga, S.; Lora, J.; Al-Garawi, A.; Martin, T.R.; Gerard, N.P.; Gerard, C. The murine CCR3 receptor regulates both the role of eosinophils and mast cells in allergen-induced airway inflammation and hyperresponsiveness. Proc. Natl. Acad. Sci. USA 2002, 99, 1479-1484. [CrossRef] [PubMed]

32. Ma, W.; Bryce, P.J.; Humbles, A.A.; Laouini, D.; Yalcindag, A.; Alenius, H.; Friend, D.S.; Oettgen, H.C.; Gerard, C.; Geha, R.S. CCR3 is essential for skin eosinophilia and airway hyperresponsiveness in a murine model of allergic skin inflammation. J. Clin. Invest. 2002, 109, 621-628. [CrossRef] [PubMed]

33. Rosenberg, H.F.; Dyer, K.D.; Foster, P.S. Eosinophils: Changing perspectives in health and disease. Nat. Rev. Immunol. 2013, 13, 9-22. [CrossRef] [PubMed]

34. Khatri, P.; Drăghici, S. Ontological analysis of gene expression data: Current tools, limitations, and open problems. Bioinformatics 2005, 21, 3587-3595. [CrossRef]

35. Rhee, S.Y.; Wood, V.; Dolinski, K.; Draghici, S. Use and misuse of the gene ontology annotations. Nat. Rev. Genetics 2008, 9, 509-515. [CrossRef]

36. Ahrens, R.; Waddell, A.; Seidu, L.; Blanchard, C.; Carey, R.; Forbes, E.; Lampinen, M.; Wilson, T.; Cohen, E.; Stringer, K.; et al. Intestinal macrophage/epithelial cell-derived CCL11/eotaxin-1 mediates eosinophil recruitment and function in pediatric ulcerative colitis. J. Immunol. 2008, 181, 7390-7399. [CrossRef]

37. Rothenberg, M.E.; Hogan, S.P. The eosinophil. Annu. Rev. Immunol. 2006, 24, 147-174. [CrossRef]

38. Gilchrist, R.B.; Ritter, L.J.; Armstrong, D.T. Oocyte-somatic cell interactions during follicle development in mammals. Anim. Reprod. Sci. 2004, 431-446. [CrossRef]

39. Birch, H.L. Extracellular Matrix and Ageing. Subcell Biochem. 2018, 90, 169-190. [CrossRef]

40. Longas, M.O.; Russell, C.S.; He, X.Y. Evidence for structural changes in dermatan sulfate and hyaluronic acid with aging. Carbohydr. Res. 1987, 159, 127-136. [CrossRef]

41. Meyer, L.J.; Stern, R. Age-dependent changes of hyaluronan in human skin. J. Invest. Dermatol. 1994, 102, 385-389. [CrossRef]

42. Lee, D.H.; Oh, J.H.; Chung, J.H. Glycosaminoglycan and proteoglycan in skin aging. J. Dermatol. Sci. 2016, 83, 174-181. [CrossRef] [PubMed]

43. Zhu, J.; Paul, W.E. CD4 T cells: Fates, functions, and faults. Blood 2008, 112, 1557-1569. [CrossRef]

44. Ohkawara, Y.; Tamura, G.; Iwasaki, T.; Tanaka, A.; Kikuchi, T.; Shirato, K. Activation and transforming growth factor-beta production in eosinophils by hyaluronan. Am. J. Respir. Cell Mol. Biol. 2000, 23, 444-451. [CrossRef] [PubMed]

45. Hamann, K.J.; Dowling, T.L.; Neeley, S.P.; Grant, J.A.; Leff, A.R. Hyaluronic acid enhances cell proliferation during eosinopoiesis through the CD44 surface antigen. J. Immunol. 1995, 154, 4073-4080. [PubMed]

46. Watanabe, Y.; Hashizume, M.; Kataoka, S.; Hamaguchi, E.; Morimoto, N.; Tsuru, S.; Katoh, S.; Miyake, K.; Matsushima, K.; Tominaga, M.; et al. Differentiation stages of eosinophils characterized by hyaluronic acid binding via CD44 and responsiveness to stimuli. DNA Cell Biol. 2001, 20, 189-202. [CrossRef] [PubMed]

47. Lamkhioued, B.; Abdelilah, S.G.; Hamid, Q.; Mansour, N.; Delespesse, G.; Renzi, P.M. The CCR3 receptor is involved in eosinophil differentiation and is up-regulated by Th2 cytokines in CD34+ progenitor cells. J. Immunol. 2003, 170, 537-547. [CrossRef] [PubMed]

48. Lloyd, C.M.; Rankin, S.M. Chemokines in allergic airway disease. Curr. Opin. Pharmacol. 2003, 3, 443-448. [CrossRef]

49. Lampinen, M.; Carlson, M.; Hakansson, L.D.; Venge, P. Cytokine-regulated accumulation of eosinophils in inflammatory disease. Allergy 2004, 59, 793-805. [CrossRef]

50. Dixon, H.; Blanchard, C.; Deschoolmeester, M.L.; Yuill, N.C.; Christie, J.W.; Rothenberg, M.E.; Else, K.J. The role of Th2 cytokines, chemokines and parasite products in eosinophil recruitment to the gastrointestinal mucosa during helminth infection. Eur J. Immunol. 2006, 36, 1753-1763. [CrossRef]

51. Stirling, R.G.; van Rensen, E.L.; Barnes, P.J.; Chung, K.F. Interleukin-5 induces CD34(+) eosinophil progenitor mobilization and eosinophil CCR3 expression in asthma. Am. J. Respir. Crit. Care Med. 2001, 164, 1403-1409. [CrossRef] [PubMed] 
52. Zhang, Z.; Schlamp, F.; Huang, L.; Clark, H.; Brayboy, L.M. Inflammaging is associated with shifted macrophage ontogeny and polarization in the aging mouse ovary. Reproduction 2020. [CrossRef] [PubMed]

53. Butterfield, J.H.; Kephart, G.M.; Frankson, J.L. Eosinophilic oophoritis: Association with positive Strongyloides stercoralis serology and clinical response to ivermectin. J. Pediatr. Adolesc. Gynecol. 2006, 19, 329-332. [CrossRef] [PubMed]

54. Lewis, J. Eosinophilic perifolliculitis: A variant of autoimmune oophoritis? Int. J. Gynecol. Pathol. 1993, 12, 360-364. [CrossRef]

55. Aust, G.; Simchen, C.; Heider, U.; Hmeidan, F.A.; Blumenauer, V.; Spanel-Borowski, K. Eosinophils in the human corpus luteum: The role of RANTES and eotaxin in eosinophil attraction into periovulatory structures. Mol. Hum. Reprod. 2000, 6, 1085-1091. [CrossRef]

56. Lotfi, R.; Lee, J.J.; Lotze, M.T. Eosinophilic granulocytes and damage-associated molecular pattern molecules (DAMPs): Role in the inflammatory response within tumors. J. Immunother. 2007, 30, 16-28. [CrossRef]

57. Duncan, F.E.; Jasti, S.; Paulson, A.; Kelsh, J.M.; Fegley, B.; Gerton, J.L. Age-associated dysregulation of protein metabolism in the mammalian oocyte. Aging Cell 2017, 16, 1381-1393. [CrossRef]

58. Pangas, S.A.; Saudye, H.; Shea, L.D.; Woodruff, T.K. Novel approach for the three-dimensional culture of granulosa cell-oocyte complexes. Tissue Eng. 2003, 9, 1013-1021. [CrossRef]

59. Xu, M.; West, E.; Shea, L.D.; Woodruff, T.K. Identification of a stage-specific permissive in vitro culture environment for follicle growth and oocyte development. Biol. Reprod. 2006, 75, 916-923. [CrossRef]

60. Shikanov, A.; Xu, M.; Woodruff, T.K.; Shea, L.D. Interpenetrating fibrin-alginate matrices for in vitro ovarian follicle development. Biomaterials 2009, 30, 5476-5485. [CrossRef]

61. Kreeger, P.K.; Deck, J.W.; Woodruff, T.K.; Shea, L.D. The in vitro regulation of ovarian follicle development using alginate-extracellular matrix gels. Biomaterials 2006, 27, 714-723. [CrossRef] [PubMed]

62. Xiao, S.; Zhang, J.; Romero, M.M.; Smith, K.N.; Shea, L.D.; Woodruff, T.K. In vitro follicle growth supports human oocyte meiotic maturation. Sci. Rep. 2015, 5, 17323. [CrossRef] [PubMed]

63. Eppig, J.J. Intercommunication between mammalian oocytes and companion somatic cells. Bioessays 1991, 13, 569-574. [CrossRef] [PubMed]

64. Richard, S.; Baltz, J.M. Prophase I arrest of mouse oocytes mediated by natriuretic peptide precursor C requires GJA1 (connexin-43) and GJA4 (connexin-37) gap junctions in the antral follicle and cumulus-oocyte complex. Biol. Reprod. 2014, 90, 137. [CrossRef] [PubMed]

65. Shuhaibar, L.C.; Egbert, J.R.; Norris, R.P.; Lampe, P.D.; Nikolaev, V.O.; Thunemann, M.; Wen, L.; Feil, R.; Jaffe, L.A. Intercellular signaling via cyclic GMP diffusion through gap junctions restarts meiosis in mouse ovarian follicles. Proc. Natl. Acad. Sci. USA 2015, 112, 5527-5532. [CrossRef] [PubMed]

66. Holt, J.E.; Lane, S.I.; Jones, K.T. The control of meiotic maturation in mammalian oocytes. Curr. Top. Dev. Biol. 2013, 102, 207-226. [CrossRef] [PubMed]

67. Sela-Abramovich, S.; Chorev, E.; Galiani, D.; Dekel, N. Mitogen-activated protein kinase mediates luteinizing hormone-induced breakdown of communication and oocyte maturation in rat ovarian follicles. Endocrinology 2005, 146, 1236-1244. [CrossRef]

68. Sun, Q.Y.; Miao, Y.L.; Schatten, H. Towards a new understanding on the regulation of mammalian oocyte meiosis resumption. Cell Cycle 2009, 8, 2741-2747. [CrossRef]

69. Fouladi-Nashta, A.A.; Raheem, K.A.; Marei, W.F.; Ghafari, F.; Hartshorne, G.M. Regulation and roles of the hyaluronan system in mammalian reproduction. Reproduction 2017, 153, R43-R58. [CrossRef]

70. Kouvidi, K.; Berdiaki, A.; Nikitovic, D.; Katonis, P.; Afratis, N.; Hascall, V.C.; Karamanos, N.K.; Tzanakakis, G.N. Role of receptor for hyaluronic acid-mediated motility (RHAMM) in low molecular weight hyaluronan (LMWHA)-mediated fibrosarcoma cell adhesion. J. Biol. Chem. 2011, 286, 38509-38520. [CrossRef]

71. Yokoo, M.; Kimura, N.; Sato, E. Induction of oocyte maturation by hyaluronan-CD44 interaction in pigs. J. Reprod. Dev. 2010, 56, 15-19. [CrossRef] [PubMed]

72. Marei, W.F.; Salavati, M.; Fouladi-Nashta, A.A. Critical role of hyaluronidase-2 during preimplantation embryo development. MHR Basic Sci. Reprod. Med. 2013, 19, 590-599. [CrossRef] [PubMed]

73. Zhu, R.; Huang, Y.H.; Tao, Y.; Wang, S.C.; Sun, C.; Piao, H.L.; Wang, X.Q.; Du, M.R.; Li, D.J. Hyaluronan up-regulates growth and invasion of trophoblasts in an autocrine manner via PI3K/AKT and MAPK/ERK1/2 pathways in early human pregnancy. Placenta 2013, 34, 784-791. [CrossRef] [PubMed] 
74. Cowman, M.K.; Lee, H.G.; Schwertfeger, K.L.; McCarthy, J.B.; Turley, E.A. The Content and Size of Hyaluronan in Biological Fluids and Tissues. Front. Immunol. 2015, 6, 261. [CrossRef] [PubMed]

75. Horton, M.R.; McKee, C.M.; Bao, C.; Liao, F.; Farber, J.M.; Hodge-DuFour, J.; Pure, E.; Oliver, B.L.; Wright, T.M.; Noble, P.W. Hyaluronan fragments synergize with interferon-gamma to induce the C-X-C chemokines mig and interferon-inducible protein-10 in mouse macrophages. J. Biol. Chem. 1998, 273, 35088-35094. [CrossRef] [PubMed]

76. Black, K.E.; Collins, S.L.; Hagan, R.S.; Hamblin, M.J.; Chan-Li, Y.; Hallowell, R.W.; Powell, J.D.; Horton, M.R. Hyaluronan fragments induce IFN $\beta$ via a novel TLR4-TRIF-TBK1-IRF3-dependent pathway. J. Inflamm. (Lond.) 2013, 10, 23. [CrossRef] [PubMed]

77. Sangha, G.K.; Guraya, S.S. Histochemical changes in acid and alkaline phosphatase activities in the growing follicles and corpora lutea of the rat ovary. Acta Morphol. Neerl. Scand. 1988, 26, 43-49.

78. Quan, N.; Harris, L.R.; Halder, R.; Trinidad, C.V.; Johnson, B.W.; Horton, S.; Kimler, B.F.; Pritchard, M.T.; Duncan, F.E. Differential sensitivity of inbred mouse strains to ovarian damage in response to low-dose total body irradiation. Biol. Reprod. 2019. [CrossRef]

79. Hornick, J.E.; Duncan, F.E.; Shea, L.D.; Woodruff, T.K. Multiple follicle culture supports primary follicle growth through paracrine-acting signals. Reproduction 2013, 145, 19-32. [CrossRef]

80. Mikkelsen, A.L.; Lindenberg, S. Morphology of in-vitro matured oocytes: Impact on fertility potential and embryo quality. Hum. Reprod. 2001, 16, 1714-1718. [CrossRef]

81. Eppig, J.J.; O'Brien, M.; Wigglesworth, K. Mammalian oocyte growth and development in vitro. Mol. Reprod. Dev. 1996, 44, 260-273. [CrossRef]

(C) 2020 by the authors. Licensee MDPI, Basel, Switzerland. This article is an open access article distributed under the terms and conditions of the Creative Commons Attribution (CC BY) license (http://creativecommons.org/licenses/by/4.0/). 